\title{
Morphological Redescription and SSU rDNA-based Phylogeny of Two Freshwater Ciliates, Uronema nigricans and Lembadion lucens (Ciliophora, Oligohymenophorea), with Discussion on the Taxonomic Status of Uronemita sinensis
}

\author{
Mingjian LIU ${ }^{1, *}$, Lifang LI $^{2, *}$, Zhishuai QU' ${ }^{1}$, Xiaotian LUO ${ }^{1}$, Saleh A. AL-FARRAJ ${ }^{3}$, Xiaofeng \\ $\mathrm{LIN}^{4}$, Xiaozhong HU ${ }^{1}$
}

\begin{abstract}
${ }^{1}$ Institute of Evolution \& Marine Biodiversity, Key Laboratory of Mariculture of the Education Ministry of China, Ocean University of China, Qingdao, China; ${ }^{2}$ Marine College, Shandong University, Weihai, China; ${ }^{3}$ Zoology Department, College of Science, King Saud University, Riyadh, Saudi Arabia; ${ }^{4}$ Guangzhou Key Laboratory of Subtropical Biodiversity and Biomonitoring, School of Life Science, South China Normal University, Guangzhou, China

${ }^{*}$ Both authors contributed equally to this work.

Abstract. The morphology and phylogeny of two poorly known species, Uronema nigricans (Müller, 1786) Florentin, 1901 and Lembadion lucens (Maskell, 1887) Kahl, 1931, were respectively collected from a eutrophic freshwater river in Shenzhen and an oligotrophic lake in Zhanjiang (both in southern China) and investigated using standard taxonomic methods. The sampled population of Uronema nigricans was characterized by a cell size of 30-40 $\mu \mathrm{m} \times 12-20 \mu \mathrm{m}$ in vivo, an elongated elliptical outline with a prominent apical plate, and $13-15$ somatic kineties. The sampled population of Lembadion lucens was characterized by a cell size of $45-80 \mu \mathrm{m} \times 20-50 \mu \mathrm{m}$ in vivo, 25-35 somatic kineties, five or six caudal kinetosomes with cilia about $20 \mu \mathrm{m}$ in length, and a single right-positioned contractile vacuole. The small subunit ribosomal RNA gene (SSU rDNA) of these species was sequenced and compared with those of their congeners to reveal nucleotide differences. The phylogenetic trees showed that the Shenzhen population of Uronema nigricans clusters with two other sequences under the name of "Uronema nigricans" (which are possibly misidentified) and then groups with Uronemita sinensis (Pan et al., 2013) Liu et al., 2016 with full support. Phylogenetic analyses indicated that genus Lembadion is monophyletic with full support provided by both Bayesian inference and maximum likelihood algorithms. Based on analyses of morphological and sequence data, Uronemita sinensis may represent a new genus between Uronema and Uronemita.
\end{abstract}

Key words: Ciliature, phylogeny, freshwater ciliate, SSU rDNA, Uronema nigricans, Lembadion lucens

Address for correspondence: Xiaozhong Hu, Lab of Protozoology, College of Fisheries, Ocean University of China, Yushan Road \#5, Qingdao, 266003, P.R. China; Tel./FAX: +86 5328203 1610; E-mail: xiaozhonghu@ouc.edu.cn 


\section{INTRODUCTION}

Ciliates in the class Oligohymenophorea de Puytorac et al., 1974 usually demonstrate global distribution (Kahl 1931, Dragesco and Dragesco-Kernéis 1986, Foissner et al. 1994, Lynn 2008, Song et al. 2009) and exhibit great biological and morphological diversity (Thompson and Kaneshiro 1968, de Puytorac et al. 1974, Kaneshiro and Holz 1976, Foissner 1995, Song and Wilbert 2000, Lynn and Small 2002, Lynn and Strüder-Kypke 2005, Jankowski 2007, de Castro et al. 2014).

Since the end of the last century, a number of new or little-known species within this group have been isolated and reported during faunistic surveys conducted in Chinese coastal areas (Ma and Song 2003; Ma et al. 2003, 2004, 2006; Wang et al. 2008; Miao et al. 2010; Fan et al. 2011a, b). Recent investigations of this class have demonstrated that it is much more diverse than previously assumed (Chantangsi et al. 2013; Liu et al. 2016; Pan H. et al. 2016; Pan X. et al. 2016, 2017; Schuster and Bright 2016), which highlights the need to conduct further studies on oligohymenophorean ciliates.

In the last decade, molecular phylogenetic analyses based on small subunit ribosomal RNA gene (SSU rDNA) sequences have increasingly been used to investigate evolutionary relationships within the class Oligohymenophorea (Strüder-Kypke et al. 2000; Shang et al. 2003, 2006; Shang and Song 2005; Miao et al. 2008, 2009; Gao et al. 2010, 2012, 2013, 2014, 2016; Gao and Katz 2014; Feng et al. 2015; Xiong et al. 2015; Zhao et al. 2016).

Uronema was first established by Dujardin (1841) with Uronema marinum as its type species. Since then, several species have been reported or transferred into this genus, but many of them were identified based only on live observation without the application of silver staining techniques and were consequently misidentified. The genus diagnosis was amended by Song et al. (2009), and according to this diagnosis, six species are currently included in the genus, namely $U$. marinum Dujardin, 1841; U. elegans Maupas, 1883; U. nigricans (Muller, 1786) Florentin, 1901; U. gallicum Pérez-Uz and Song, 1995; U. heteromarinum Pan et al., 2010; and U. orientalis Pan et al., 2015 (Thompson and Evans 1968, Song 1991, Foissner et al. 1994, Pérez-Uz and Song 1995, Petz et al. 1995, Song et al. 2009, Pan H. et al. 2010, Pan X. et al. 2015). Among these, only $U$. gallicum lacks molecular information and has not been recorded from China. Two incomplete SSU rDNA sequences under the name of "U. nigricans" have been submitted to the National Center for Biotechnology Information (NCBI), however, they are possibly misidentified after reinvestigation.

Perty (1849) first established the genus Lembadion and transferred Bursaria bullina Müller, 1786 into this genus and designated it as a type species. Maskell (1887) established a new genus Thurophora and described Thurophora lucens. Stokes (1887) reported a new species under the name of Hymenostoma magnum. Kahl (1931) transferred both Thurophora lucens and Hymenostoma magnum into the genus Lembadion. So far, this genus includes seven nominal species, the latest being Lembadion planus Obolkina, 2006 (Dragesco 1960, 1965; Foissner et al. 1994; Esteban et al. 2000; Obolkina 2006).

In the present work, two freshwater species were documented based on live observation and silver staining preparations, and their SSU rDNA sequences were characterized and analyzed to determine their phylogenetic position within the class Oligohymenophorea.

\section{MATERIALS AND METHODS}

\section{Sample collection and cultivation}

Uronema nigricans was collected from a eutrophic freshwater (water temperature about $15^{\circ} \mathrm{C}, \mathrm{pH}$ 7.6) river in Shenzhen $\left(22^{\circ} 32^{\prime} 19^{\prime \prime} \mathrm{N} ; 114^{\circ} 06^{\prime} 45^{\prime \prime} \mathrm{E}\right)$, southern China, on December 7, 2015 (Fig. 1A). In this case, water samples were collected by scraping the surface of the riverbank, collecting water samples along with organic debris.

Lembadion lucens was collected from Huguangyan Lake, an oligotrophic lake in Zhanjiang $\left(21^{\circ} 08^{\prime} 38^{\prime \prime} \mathrm{N} ; 110^{\circ} 16^{\prime} 20^{\prime \prime E}\right)$, southern China, on October 24, 2013 when the water temperature was $24.5^{\circ} \mathrm{C}$ and its $\mathrm{pH}$ was 8.2 (Fig. 1B). In this case, water samples were collected directly along with some organic debris.

Raw cultures were maintained in Petri dishes using habitat water at room temperature $\left(24^{\circ} \mathrm{C}-25^{\circ} \mathrm{C}\right)$ with grains of rice or artificial fish food granules added to promote the growth of bacterial food for the ciliates.

\section{Morphological methods}

Living cells were isolated from raw cultures with micropipettes and observed using bright-field and differential interference contrast microscopy at $100 \times-1,000 \times$ magnification. The protargol staining method described by Wilbert (1975) was used to reveal the ciliature and nuclear apparatus. In vivo measurements were conducted at a magnification of $40 \times-1,000 \times$. Counts and measurements of stained specimens were performed at a magnification of $1,000 \times$. Drawings of living cells were produced using freehand sketches and photomicrographs, and drawings of silver-stained specimens were produced with the help of a camera lucida (Pan X. et al. 2016). The terminology used is according to Song (1991) and Foissner et al. (1994). 


\section{DNA extraction, PCR amplification, and gene se- quencing}

Genomic DNA extraction, polymerase chain reaction (PCR), and sequencing of the SSU rDNA were carried out according to the methods of Huang et al. (2014). To remove potential contamination, a micropipette was used to isolate and wash several cells with filtered $(0.22 \mu \mathrm{m})$ habitat water. Extraction of genomic DNA was performed using a DNeasy Blood \& Tissue Kit (Qiagen, Hilden, Germany), following the manufacturer's instructions. Primers $18 \mathrm{~S}-\mathrm{F}$ (5'-AAC CTG GTT GAT CCT GCC AGT-3') and 18S-R (5'-TGA TCC TTC TGC AGG TTC ACC TAC-3') were used for SSU rDNA amplification (Medlin et al. 1988). To minimize the possibility of PCR amplification errors, Q5 ${ }^{\circledR}$ Hot Start High-Fidelity DNA Polymerase (New England BioLabs, USA) was used. Sequencing was performed bidirectionally on an ABI 3700 sequencer (GENEWIZ Biotechnology Co., Ltd., Beijing, China).

\section{Phylogenetic analyses}

The SSU rDNA sequences of Lembadion lucens and Uronema nigricans were aligned with the sequences of 75 other taxa downloaded from the NCBI genetic sequence database (GenBank) for the phylogenetic analyses. The accession numbers were provided after the species names in the phylogenetic trees. Nolandia orientalis, Placus salinus, and Prorodon ovum were selected as outgroups. All sequences were aligned using MUSCLE software from the European Bioinformatics Institute (available at http://www.ebi.ac.uk/ Tools/msa/muscle/). The resulting alignment was manually edited using the program BioEdit 7.0.5.2 (Hall 1999), and both ends of the alignment were trimmed. The final alignment, including 1834 positions and 77 taxa, was used for the phylogenetic analyses.

Maximum likelihood (ML) analysis with 1,000 bootstrap replicates was performed to estimate the reliability of internal branches using RAxML-HPC2 on XSEDE 8.2.8 (Stamatakis 2014), with the GTRGAMMA model provided on the online server CIPRES Science Gateway (Miller et al. 2010). Bayesian inference (BI) analysis was performed using MrBayes 3.2.6 on XSEDE 3.2.6 (Ronquist and Huelsenbeck 2003) on the CIPRES Science Gateway (available at http://www.phylo.org/sub_sections/portal) with the best-fit model GTR + I + G selected by Akaike information criterion (AIC) using MrModeltest 2 (Nylander 2004). Markov chain Monte Carlo (MCMC) simulations were then run with two sets of four chains for 4,000,000 generations at a sampling frequency of 100 and a burn-in of 10,000 trees $(25 \%)$. All remaining trees were used to calculate the posterior probability (PP) using a $50 \%$ majority rule consensus. MEGA 4.0 (Tamura et al. 2007) analyses were used to visualize the tree topologies. Systematic classification followed Lynn (2008).

\section{Comparison of the SSU rDNA sequences}

The SSU rDNA sequences of Uronema nigricans and Lembadion lucens, along with the sequences of their congeners obtained from the GenBank database, were aligned using BioEdit 7.0.5.2 (Hall 1999). After deleting both ends of the alignments, the numbers of unmatched sites and sequence similarities were calculated. The alignments were then modified manually by removing identical nucleotides with BioEdit 7.0.5.2 (Hall 1999), resulting in nucleotide matrices.

\section{RESULTS}

Class Oligohymenophorea de Puytorac et al., 1974

\section{Subclass Scuticociliatia Small, 1967 \\ Order Philasterida Small, 1967 \\ Family Uronematidae Thompson, 1964 \\ Genus Uronema Dujardin, 1841}

Uronema nigricans (Müller, 1786) Florentin, 1901

(Figs 2A, C, F, 3A-M, Table 1)

Uronema nigricans has been redescribed several times since its first recording. However, high-quality photomicrographs of protargol-stained individuals and SSU rDNA sequencing were not available previously. In this study, we determined an improved diagnosis and a detailed redescription based on previous and present data.

Improved diagnosis: Cell size ca. 20-50 $\mu \mathrm{m}$ $\times 10-25 \mu \mathrm{m}$ in vivo with a truncated apical plate; pellicle thin and inconspicuously notched, with ridges located longitudinally along ciliary rows; $10-15$ somatic kineties, somatic kinety 1 usually shortened, posterior end extending at about three fourths to four fifths of cell; oral apparatus typical of the genus, membranelle 1 clearly separated from other membranelles; freshwater and brackish water habitat.

Deposition of voucher slides: Two voucher slides (registration nos. LMJ2015120701-1 and LMJ2015120701-2) have been deposited in Laboratory of Protozoology, Ocean University of China, Qingdao, China.

Morphological description of Shenzhen population: Cell size in vivo about $30-40 \mu \mathrm{m} \times 12-20 \mu \mathrm{m}$. Cell shape elongate-elliptical in outline. Anterior end flat, with a prominent apical plate. Posterior part broadly rounded (Figs 2A, 3A-C, E). Buccal field about half body length and slightly concave. Pellicle thin and inconspicuously notched with ridges located longitudinally along ciliary rows (Figs 2A, 3A, E). No extrusomes detected in vivo. Cytoplasm colorless to slightly grayish, containing several bar-like crystals distributed in anterior and posterior portions. Well-fed individuals containing several to many grayish-green food vacuoles, leading to a dark gray body color at low magnifications (Figs 3A-E). Single contractile vacuole subcaudally positioned, about $3-4 \mu \mathrm{m}$ in diameter when fully expanded, pulsating at intervals of 6-8 s (Figs 2A, 3A). Somatic cilia about 5-7 $\mu \mathrm{m}$ long in vivo, densely arranged (Figs 2A, 3A-E); single caudal cilium approximately 15-20 $\mu \mathrm{m}$ long (Figs $2 \mathrm{~A}, 3 \mathrm{~A}, \mathrm{C}, \mathrm{D}$ ). 


\section{Liu et al.}

Table 1. Morphometric data of Uronema nigricans (Müller, 1786) Florentin, 1901 (upper line) and Lembadion lucens (Maskell, 1887) Kahl, 1931 (lower line) from life and after protargol staining. Some specific characters of these two species are shown separately.

\begin{tabular}{|c|c|c|c|c|c|c|c|}
\hline Characteristics $^{\mathrm{a}}$ & Min & Max & Mean & Median & SD & $\mathrm{CV}$ & $n$ \\
\hline \multirow[t]{2}{*}{ Body length (living cells) $(\mu \mathrm{m})$} & 30 & 40 & 33.6 & 32 & 3.85 & 11.4 & 5 \\
\hline & 45 & 70 & 55.6 & 55 & 7.26 & 13.1 & 9 \\
\hline \multirow[t]{2}{*}{ Body width (living cells) $(\mu \mathrm{m})$} & 12 & 20 & 15.2 & 15 & 2.95 & 19.4 & 5 \\
\hline & 20 & 40 & 30.6 & 30 & 5.83 & 19.1 & 9 \\
\hline \multirow[t]{2}{*}{ Body length $(\mu \mathrm{m})$} & 25 & 35 & 28.7 & 30 & 2.60 & 9.1 & 15 \\
\hline & 45 & 60 & 53.0 & 53 & 4.73 & 8.9 & 38 \\
\hline \multirow[t]{2}{*}{ Body width $(\mu \mathrm{m})$} & 12 & 18 & 15.3 & 15 & 1.87 & 12.2 & 15 \\
\hline & 25 & 50 & 40.1 & 40 & 5.46 & 13.6 & 38 \\
\hline \multirow[t]{2}{*}{ Oral length $(\mu \mathrm{m})$} & 10 & 13 & 11.5 & 11 & 0.83 & 7.2 & 15 \\
\hline & 30 & 45 & 38.4 & 40 & 3.38 & 8.8 & 35 \\
\hline \multirow[t]{2}{*}{ Oral length/Body length } & 0.37 & 0.46 & 0.40 & 0.40 & 0.03 & 7.2 & 15 \\
\hline & 0.58 & 0.90 & 0.73 & 0.73 & 0.08 & 10.6 & 35 \\
\hline \multirow[t]{2}{*}{ Number of somatic kineties (SK) } & 13 & 15 & 14.3 & 14 & 0.59 & 4.2 & 15 \\
\hline & 25 & 30 & 27.9 & 28 & 1.13 & 4.0 & 34 \\
\hline \multirow[t]{2}{*}{ Number of kinetids in $\mathrm{SK}_{1}$} & 15 & 19 & 16.6 & 16 & 0.99 & 5.9 & 15 \\
\hline & 14 & 23 & 24.3 & 19 & 3.28 & 5.0 & 14 \\
\hline \multirow[t]{2}{*}{ Number of kinetids in $\mathrm{SK}_{\text {mid }}$} & 12 & 15 & 13.5 & 13 & 0.92 & 6.8 & 15 \\
\hline & 21 & 27 & 18.5 & 24 & 1.20 & 17.7 & 22 \\
\hline
\end{tabular}

Uronema nigricans

Number of kinetids in $\mathrm{SK}_{\mathrm{n}}$

Number of dikinetids in $\mathrm{SK}_{\mathrm{n}}$

Number of dikinetids in $\mathrm{SK}_{1}$

Number of dikinetids in $\mathrm{SK}_{\text {mid }}$

Diameter of macronucleus $(\mu \mathrm{m})$

$\begin{array}{rrrrrrr}15 & 20 & 17.3 & 17 & 1.49 & 8.6 & 15 \\ 3 & 10 & 4.6 & 4 & 1.99 & 43.3 & 15 \\ 4 & 14 & 7.3 & 7 & 2.76 & 38.0 & 15 \\ 2 & 12 & 4.7 & 4 & 2.76 & 58.4 & 15 \\ 8 & 11 & 9.6 & 10 & 1.06 & 11.0 & 15\end{array}$

\section{Lembadion lucens}

Oral width $(\mu \mathrm{m})$

Length of macronucleus $(\mu \mathrm{m})$

width of macronucleus $(\mu \mathrm{m})$

Diameter of micronucleus $(\mu \mathrm{m})$

Number of kinety rows of caudal cilia

Number of basal bodies in caudal cilia row on dorsal side

$\begin{array}{rrrrrrr}20 & 35 & 26.1 & 25 & 4.55 & 17.4 & 35 \\ 15 & 30 & 24.6 & 25 & 4.27 & 17.4 & 25 \\ 5 & 15 & 10.9 & 10 & 2.77 & 25.5 & 25 \\ 2 & 3 & 2.4 & 2 & 0.53 & 22.0 & 7 \\ 2 & 2 & 2.0 & 2 & 0.00 & 0.0 & 30 \\ 5 & 6 & 5.7 & 6 & 0.48 & 8.5 & 30 \\ 2 & 3 & 2.1 & 2 & 0.25 & 12.3 & 30\end{array}$

Number of basal bodies in caudal cilia row on ventral side

${ }^{a} \mathrm{CV}$, coefficient of variation in \%; Max, maximum; Mean, arithmetic mean; Min, minimum; $n$, number of individuals examined; SD, standard deviation; $\mathrm{SK}_{1}$, the kinety on right of buccal field; $\mathrm{SK}_{\text {mid }}$, the middle kinety on dorsal side; $\mathrm{SK}_{\mathrm{n}}$, the kinety on left of buccal field. 


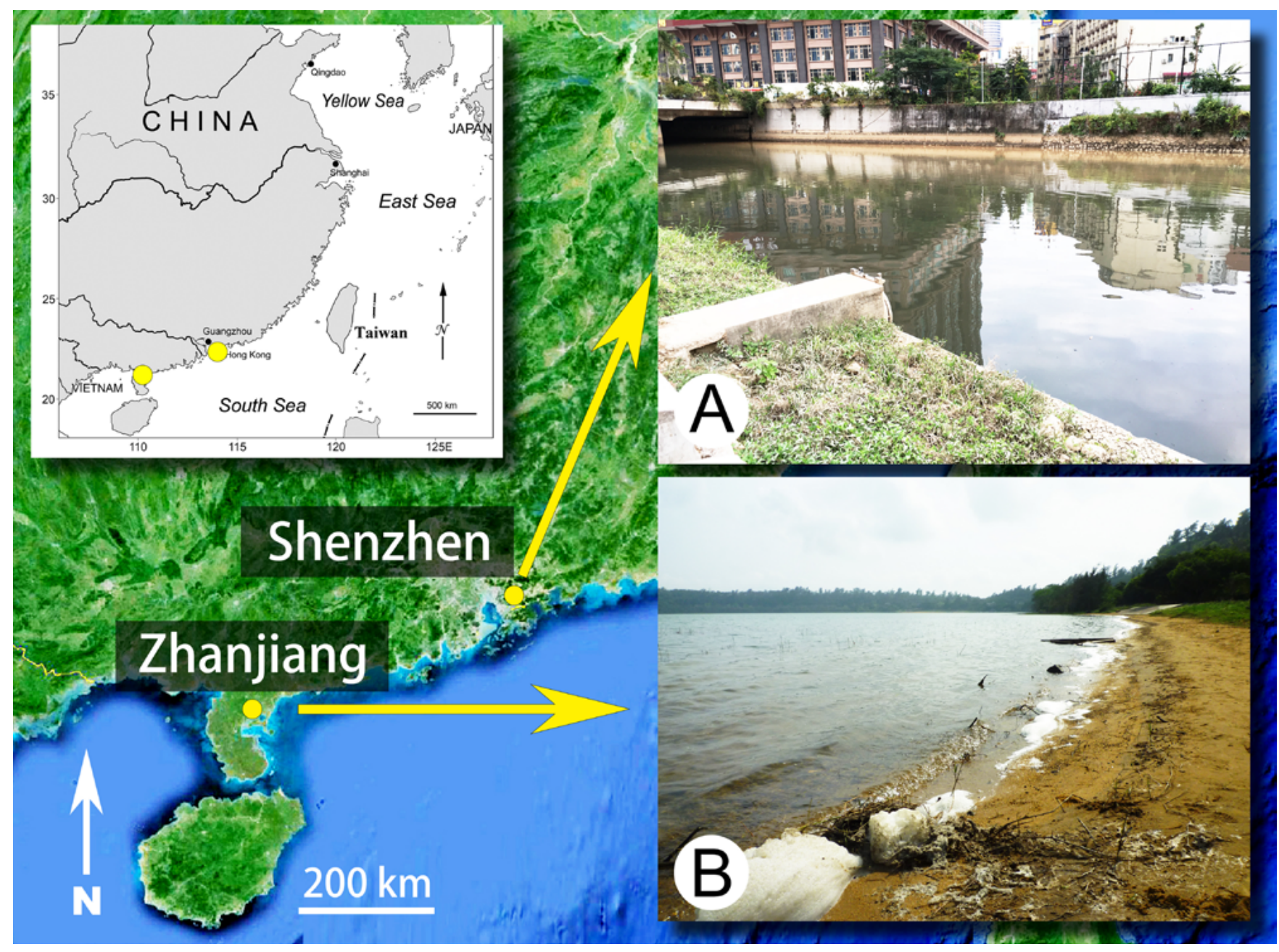

Fig. 1. Map and sampling site. The yellow dots on the map and two corresponding photographs (A, B) show the collecting sites. (A) Freshwater river in Shenzhen, southern China $\left(22^{\circ} 32^{\prime} 19^{\prime \prime N}\right.$; $\left.114^{\circ} 06^{\prime} 45^{\prime \prime E}\right)$. (B) Huguangyan Lake, an oligotrophic lake in Zhanjiang, southern China $\left(21^{\circ} 08^{\prime} 38^{\prime \prime} \mathrm{N} ; 110^{\circ} 16^{\prime} 20^{\prime \prime} \mathrm{E}\right)$.

Single spherical to oval macronucleus located centrally or slightly ahead of mid-body, about $10 \mu \mathrm{m}$ in diameter in protargol preparations (Figs 2F, 3J-M). Locomotion by swimming moderately fast, but cells observed mostly crawling on substrates or resting on the bottom of petri dish when not disturbed.

Somatic ciliature as shown in Figs 2C, F, 3F-M. Thirteen to fifteen somatic kineties (SKs) arranged longitudinally, forming a small glabrous area at anterior end (Figs 2C, F, 3J-M). Somatic kinety 1 (SK1, kinety on right of buccal field) usually shorter than other SKs, with posterior end terminating at about three fourths to four fifths of cell (Figs 2C, 3J, L). Somatic kinety $\mathrm{n}$ (SKn, kinety on left of buccal field) located slightly posteriorly with anterior end commencing at front part of membranelle 1 (M1) (Figs 2C, 3J, L).
In general, each kinety composed of closely arranged dikinetids in anterior part and loosely arranged monokinetids posteriorly (Figs 2C, F, 3J-M). Dikinetids of some individuals extending to the posterior end, almost occupying four-fifths of SK. Somatic kinety 1 composed of 15-19 kinetids, including four to 14 dikinetids, while SKn composed of 15-20 kinetids, with three to 10 dikinetids (Figs 2C, 3J, L). The middle SK on the dorsal side comprising 12-15 kinetids (Figs 2F, $3 \mathrm{~K}, \mathrm{M})$.

Buccal apparatus similar to its congeners (Figs 2C, 3I, L). Membranelle 1 (M1) single-rowed and positioned near apical plate, clearly separated from other membranelles. It consisted of 5 or 6 basal bodies arranged in one row and a central basal body slightly deviated to the left (towards SKn) (Figs 2C, 3I, J, L). 

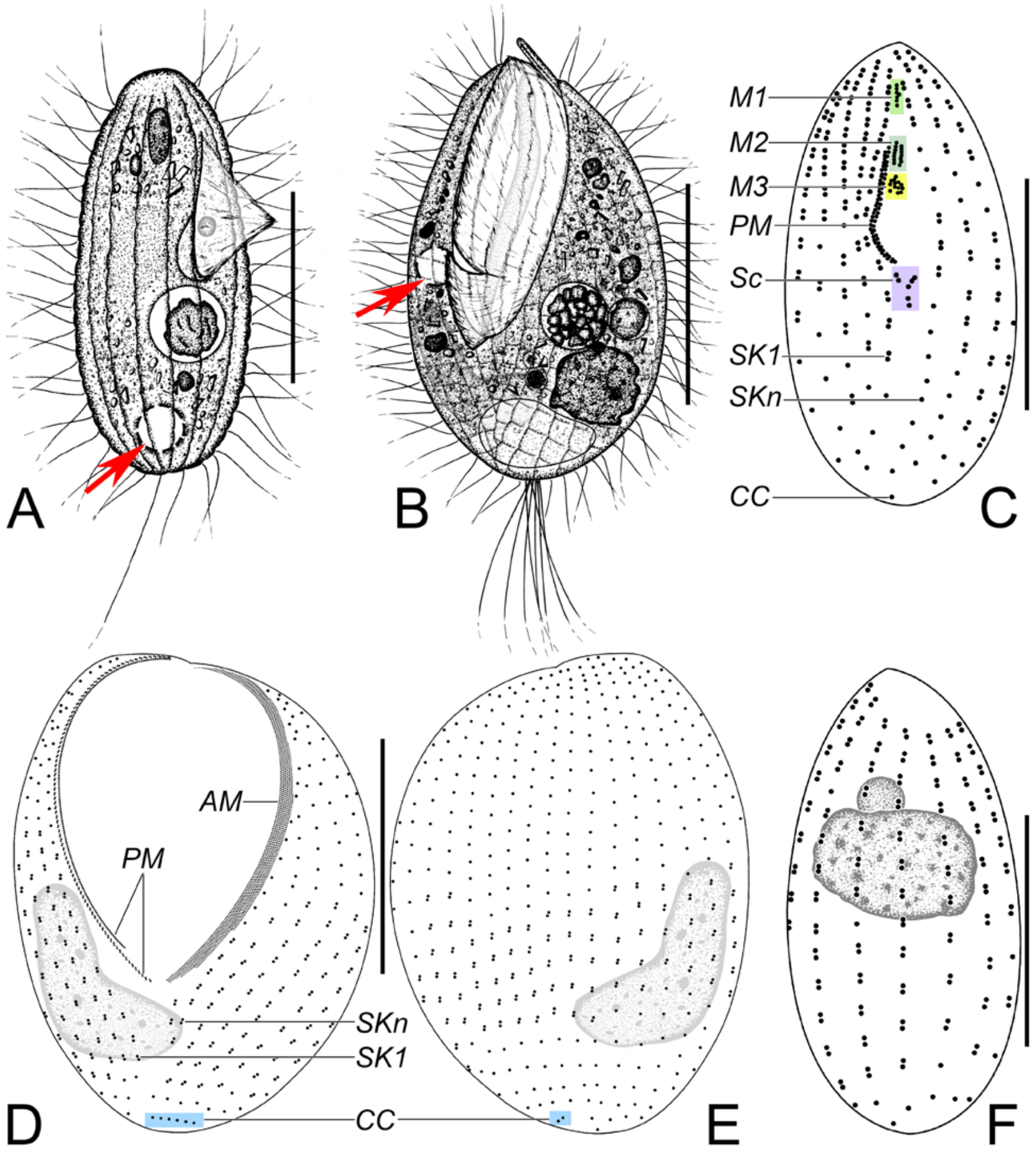

Fig. 2. Uronema nigricans and Lembadion lucens in vivo (A, B) and after protargol (C-F) staining. (A, B) Right ventrolateral view (A) and ventral view (B) of a representative individual of Uronema nigricans and Lembadion lucens, respectively, arrows point to contractile vacuole. (C-F) Ventral (C, D) and dorsal (E, F) views of representative individuals of Uronema nigricans and Lembadion lucens, respectively, to show the ciliature and nuclear apparatus. AM, adoral membranelle; CC, basal body of caudal cilia; M1-3, membranelles 1-3; PM, paroral membrane; Sc, scutica; SK1, the somatic kinety right of buccal field; SKn, the somatic kinety left of buccal field. Scale bars: $15 \mu \mathrm{m}(\mathrm{A}, \mathrm{C}, \mathrm{F}) ; 30 \mu \mathrm{m}(\mathrm{B}, \mathrm{D}, \mathrm{E})$. 

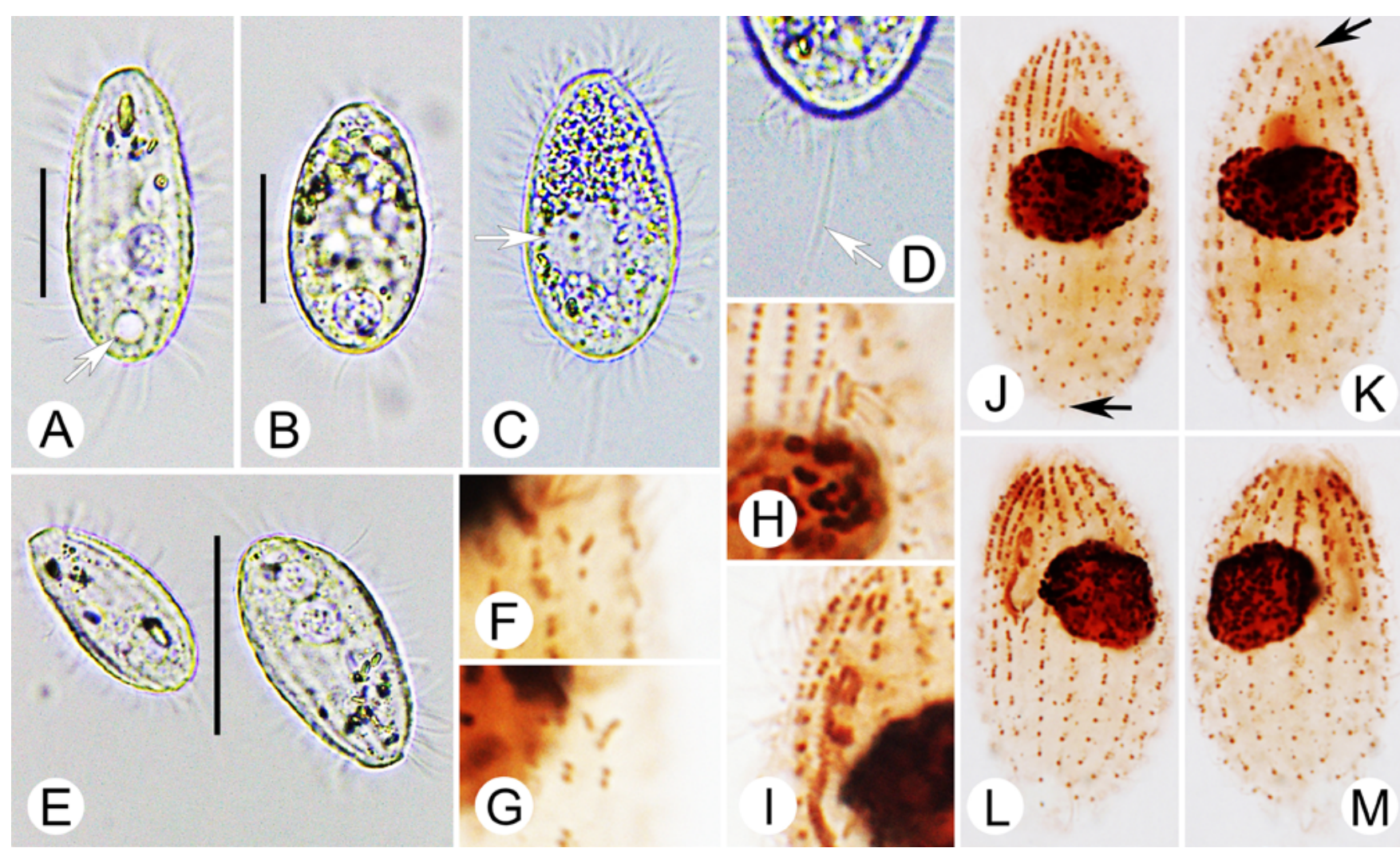

Fig. 3. Photomicrographs of Uronema nigricans from life (A-E, in bright field illumination) and after protargol (F-M) staining. (A-C) Right ventrolateral views of representative individuals, with cell in $\mathrm{C}$ slightly depressed. Arrow in A shows contractile vacuole, while in $\mathrm{C}$ indicates macronucleus. (D) View of caudal portion of another cell, arrow points to caudal cilium. (E) Different body sizes, showing conspicuous apical plate. (F, G) Ventral views of stained individuals, indicating the structure of scutica. (H, I) Portion views of oral apparatus, revealing the number of kinety rows in M2 (two rows in $\mathrm{H}$ and three rows in I). (J, K) Ventral $(\mathrm{J})$ and dorsal $(\mathrm{K})$ view of a representative individual to show the ciliature and nuclear apparatus. Arrow in J points to basal body of caudal cilium, arrow in $\mathrm{K}$ indicating the apical plate. (L, M) Left ventrolateral (L) and right dorsolateral (M) view of another stained individual to show the ciliature and oral apparatus. Scale bars: $15 \mu \mathrm{m}(\mathrm{A}, \mathrm{B}) ; 30 \mu \mathrm{m}(\mathrm{E})$.

Membranelle 2 (M2) almost equal to M1 in length and composed of two or three longitudinal rows of basal bodies (Figs 2C, 3H, I, L). Membranelle 3 (M3) composed of about seven to nine basal bodies, forming a small patch (Figs 2C, 3I, L). Paroral membrane (PM) on right of shallow buccal cavity, composed of two rows of basal bodies in a zigzag pattern, and extending anteriorly to about middle portion of M2 (Figs 2C, $3 \mathrm{H}-\mathrm{J}, \mathrm{L})$. Scutica observed usually consisting of two or three pairs of basal bodies with one or two basal bodies positioned posteriorly (Figs 2C, 3F, G, L).

Class Oligohymenophorea de Puytorac et al., 1974

Subclass Peniculia Fauré-Fremiet in Corliss, 1956 Order Peniculida Fauré-Fremiet in Corliss, 1956
Family Lembadionidae Jankowski in Corliss, 1979 Genus Lembadion Perty, 1849 Lembadion lucens (Maskell, 1887) Kahl, 1931 (Figs 2B, D, E, 4A-K, Table 1)

Although Lembadion lucens had been redescribed using silver staining methods several times, its SSU rDNA sequence remained unavailable. Moreover, it had never been found in China. Based on all data available, the species is now redescribed below.

Improved diagnosis: Cell size approximately $45-80$ $\mu \mathrm{m} \times 20-50 \mu \mathrm{m}$ in vivo; cell shape oval to long ellipsoidal; large and wide buccal field, occupying about 60 $90 \%$ of body length; single contractile vacuole centrally positioned near right margin of cell; 25-35 somatic kineties; single kidney- or L-shaped macronucleus; seven to 
10 caudal kinetosomes arranged into two rows, with cilia about $20-30 \mu \mathrm{m}$ in length; freshwater habitat.

Deposition of voucher slides: Two voucher slides (registration nos. QZS2013102408 and LXT2013102407) have been deposited in Laboratory of Protozoology, Ocean University of China, Qingdao, China.

Morphological description based on Zhanjiang population: Cell size in vivo about $45-70 \mu \mathrm{m} \times 20-40$ $\mu \mathrm{m}$. Ratio of length to width approximately $3: 2$ to $2: 1$. Cell shape constant, oval to long elliptical in outline. Anterior part slightly narrowed with a prominence, and posterior part rounded (Figs 2B, 4A). Ventral side deeply concave, while dorsal side prominently convex (Fig. 4D). Buccal field extremely large and wide, about 30-45 $\mu \mathrm{m}$ long and 20-35 $\mu \mathrm{m}$ wide, occupying three-fourths to four-fifths of body length, with buccal cilia about $20 \mu \mathrm{m}$ in length (Figs $2 \mathrm{~B}, 4 \mathrm{~A}, \mathrm{~B}$ ). Somatic cilia approximately $8 \mu \mathrm{m}$ long in vivo and densely arranged along long axis of body (Figs 2B, 4B). Caudal cilia about $20 \mu \mathrm{m}$ long (Figs $2 \mathrm{~B}, 4 \mathrm{~B}$ ). Pellicle thin with rectangular meshes arranged on middle and posterior parts of cell's surface. Each mesh has single somatic cilium inserted centrally. Extrusomes not detected. Endoplasm colorless to grayish, containing several to numerous food vacuoles and bar-like refractile granules. Many small spherical lipid droplets located beneath pellicle (Figs 4A-C). Single contractile vacuole, about $7 \mu \mathrm{m}$ in diameter when fully expanded, positioned at mid-body near right margin of cell on dorsal side (Figs 2B, 4C). Collecting canal not detected. Single kidneyor L-shaped macronucleus subequatorially positioned, right side of median line, about $15-30 \mu \mathrm{m} \times 5-15 \mu \mathrm{m}$ in size (Figs 2D, E, 4F, H). One spherical micronucleus closely associated with macronucleus, approximately $2.5 \mu \mathrm{m}$ in diameter (Fig. 4H). Locomotion achieved by swimming moderately fast while rotating about main body axis continuously without pause.

Ciliature as shown in Figs 2D, E, 4E-K. About 25-30, usually 28, almost bipolar SK observed. Each SK composed of dikinetids in middle portion and monokinetids at both ends (Figs 2D, E, 4F, G, J). Middle somatic kinety on dorsal side consisting of about 21-27 basal bodies, of which four to six dikinetids (Figs 2E, $4 \mathrm{G}, \mathrm{J})$. Number of dikinetids gradually increasing from middle somatic kinety, in both left and right directions, to approximately eight to 12 dikinetids (Figs 2D, E). Somatic kinety 1 (kinety on right of buccal field) composed of about 14-23 basal bodies. Basal bodies of caudal cilia arranged into two rows, distributed at posterior part of cell: row on dorsal side consisting of five or six basal bodies, while another row on ventral side composed of two or three basal bodies (Figs 2D, 4I).

Buccal apparatus typical of genus, containing one adoral membranelle (AM) and two paroral membranes (PMs) (Figs 2D, 4F). Adoral membranelle composed of seven rows of densely packed basal bodies located on left margin of buccal cavity. Inner three rows (apart from SKn) almost identical in length while outer rows shortened gradually (Figs 2D, 4F, K). Two PMs positioned on right margin of buccal cavity. Kinetids in outer PM (near SK1) arranged in zigzag pattern and longer than inner one, while inner PM seems to be composed of single row of kinetids (Figs 2E, 4F). Small bald area presents below posterior end of buccal apparatus, between SKn (kinety on left of buccal field) and SK1 (Figs 2D, 4E, K). Two pairs of basal bodies close to posterior end of SKn (Figs 2D, 4K).

Silverline system visible in vivo and after protargol staining, typical for genus, composed of longitudinally arranged silverlines located between SKs, and horizontally arranged silverlines connecting two neighboring longitudinal ones at mid and posterior part of the body, forming rectangular meshes where somatic cilia inserted centrally (Fig. 4E).

\section{SSU rDNA sequence and phylogenetic analyses (Figs 5 and 6)}

The SSU rDNA sequences of Uronema nigricans and Lembadion lucens have been deposited in the GenBank database with accession numbers, lengths, and guaninecytosine (GC) content as follows: MF072399, $1706 \mathrm{bp}$, $43.20 \%$ and MF072398, $1603 \mathrm{bp}, 44.85 \%$, respectively.

The topologies of the SSU rDNA trees constructed using ML and BI analyses are similar; therefore, only the ML tree is presented here with support values from both algorithms (Fig. 5). Both analyses consistently placed our population of Uronema nigricans in a clade with Uronemita sinensis and two sequences under the name of "Uronema nigricans" with full support values (100\% $\mathrm{ML}, 1.00 \mathrm{BI})$. The clade is clustered with another three Uronemita species with full support. Lembadion lucens is placed with Lembadion bullinum and Lembadion sp., forming a monophylum with maximum support (100\% ML, 1.00 BI). This clade clustered with other species in Peniculida with full support (100\% ML, $1.00 \mathrm{BI})$.

The results of the sequence comparisons are shown in Fig. 6. Uronema nigricans MF072399 differs from Uronema nigricans JF973324 and Uronema nigricans JN638884 in 10 nucleotides, having a sequence 

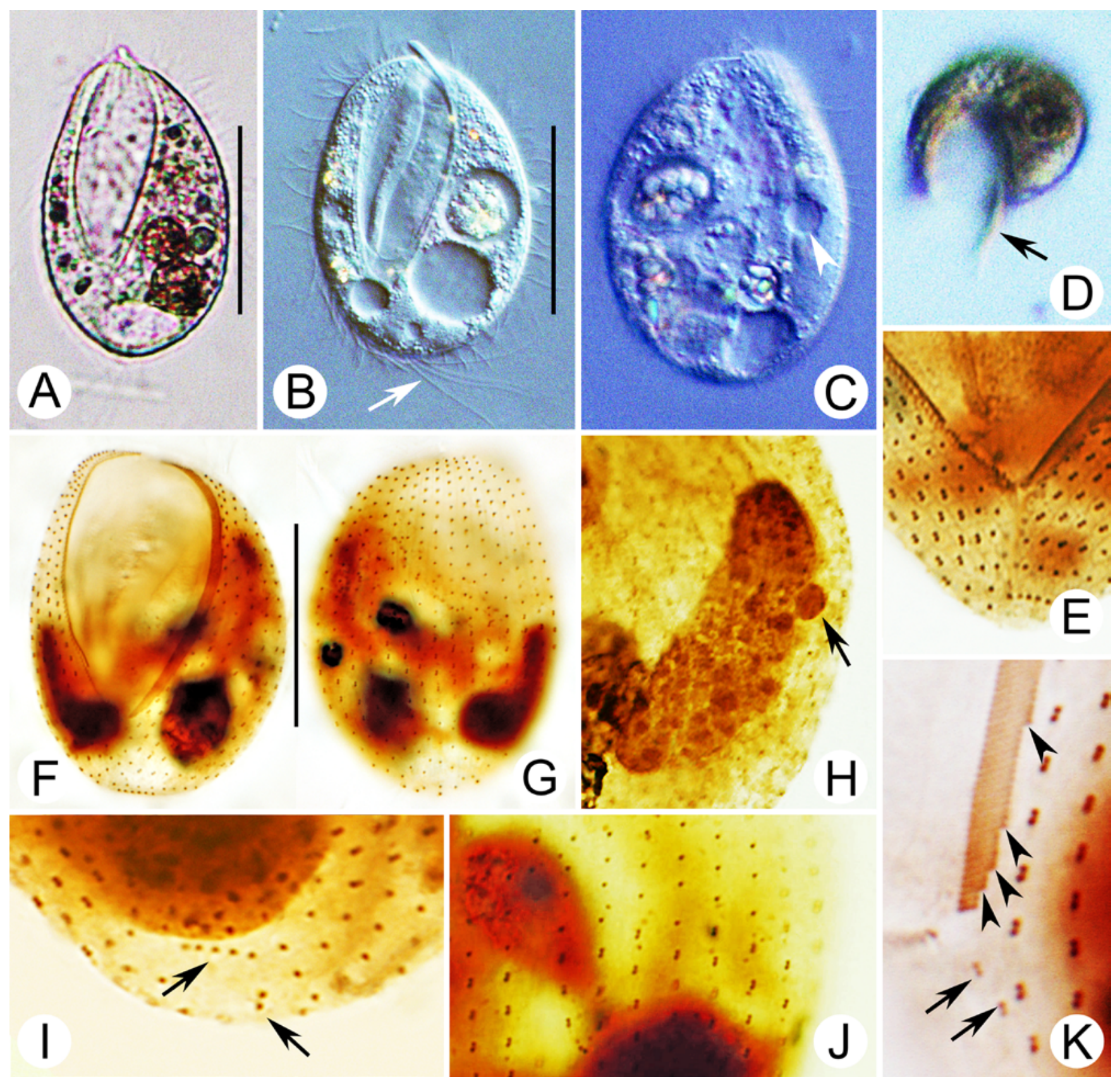

Fig. 4. Photomicrographs of Lembadion lucens from life (A-D, with A in bright field illumination and others in DIC microscopy) and after protargol staining (E-K). (A, B) Ventral views of representative individuals, cell in B was slightly depressed. Arrow shows caudal cilia. (C) Dorsal view, arrowhead points to the contractile vacuole. (D) Apical view, revealing the shape of cross section. Arrow shows oral cilia. (E) Ventral view of a stained cell, showing the silverline system. (F, G) Ventral (F) and dorsal (G) view of a representative individual, to show the ciliature and nuclear apparatus. $(\mathrm{H})$ Micronucleus (arrow) and macronucleus. (I) Ventral view of posterior portion. Arrows depict two basal body rows of caudal cilia. (J) Mid portion of dorsal view, illustrating the monokinetids and dikinetids. (K) Detailed view, arrows show the two separated pairs of basal bodies and arrowheads indicate the posterior ends of four gradually shortened outer rows of adoral membranelle. Scale bars: $30 \mu \mathrm{m}$. 


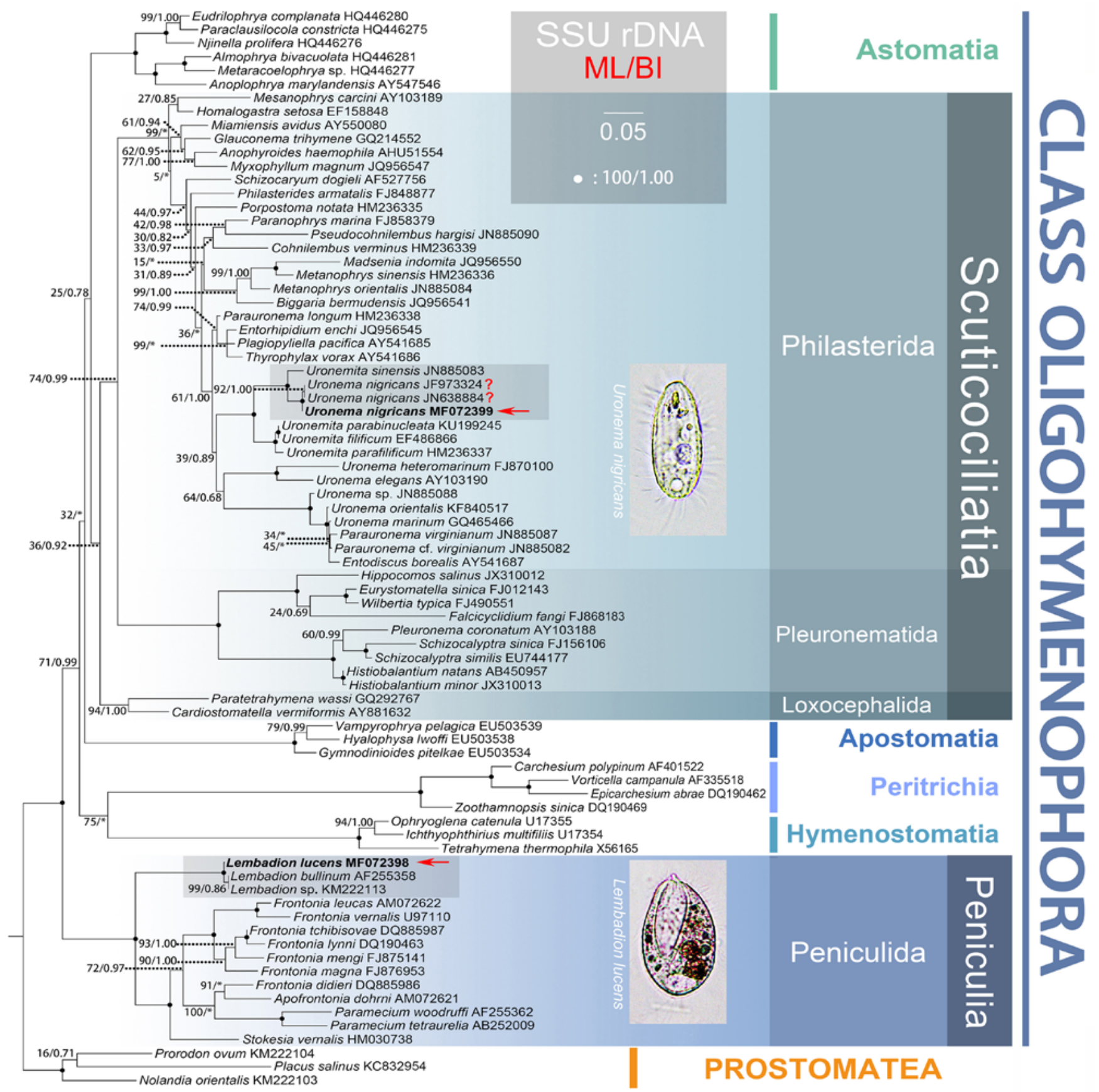

Fig. 5. Maximum likelihood (ML) tree inferred from SSU rDNA sequences, showing the position of Uronema nigricans and Lembadion lucens (red arrows). Numbers near branches denote ML bootstrap value/BI posterior probability. Asterisks $(*)$ indicate topologies that differ between the ML and BI analyses. Fully supported (100\%/1.00) branches are marked with solid circles. Question marks (?) in red color indicate that the two sequences are possibly misidentified. The scale bar corresponds to 5 substitutions per 100 nucleotide positions. All branches are drawn to scale. Systematic classification mainly follows Lynn (2008). 


\section{Comparison of the SSU rDNA sequences}

\begin{tabular}{|c|c|c|c|c|c|c|c|c|}
\hline$\%$ & $n$ & sites position & \multicolumn{3}{|c|}{ 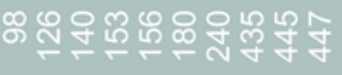 } & 劣视 & & ذ \\
\hline ID & ID & Uronema nigricans MF072399 & \multicolumn{3}{|c|}{ C CGTCTATA T } & C - A C T T GGGT & & T GA A GC T C \\
\hline 99.0 & 10 & Uronema nigricans JF973324? & \multicolumn{3}{|c|}{ C CGTCTATAT } & C - A C T T GGG T & & $\mathbf{T} \mathbf{G}-\mathrm{T} \mathbf{T} \mathbf{C}-$ \\
\hline 99.0 & 10 & Uronema nigricans JN638884? & \multicolumn{3}{|c|}{ C C G T C T A T A T } & C - A C T T GGG T & & - T T C - \\
\hline 97.7 & 24 & Uronemita sinensis JN885083 & \multicolumn{3}{|c|}{ A G A G A C T C G C } & T T G T A C T T A C & & A A A A G C T C \\
\hline & & sites position & & & & & & \\
\hline ID & ID & Uronema niqricans MF072399 & A C & ID & ID & Lembadion Iucens MF072 & & T C T T C C GG \\
\hline 99.0 & 10 & Uronema nigricans JF973324? & $-\mathbf{A} \mathbf{T}$ & 99.5 & 8 & Lembadion bullinum AF255 & & C T C C T T A A \\
\hline 99.0 & 10 & Uronema nigricans JN638884? & $-\mathbf{A} \mathbf{T}$ & 99.5 & 7 & Lembadion sp. KM222113 & & C T T C T T A A \\
\hline 97.7 & 24 & Uronemita sinensis JN885083 & A C - - & & & & & \\
\hline
\end{tabular}

Fig. 6. Sequence comparison of the small subunit ribosomal RNA gene determined by BioEdit 7.0.5.2 (Hall 1999), showing the unmatched nucleotides of Uronema nigricans MF072399 and Lembadion lucens MF072398 with their sister sequences in the same clades, respectively (see Fig. 5). Nucleotide positions are given at the top of each column. Insertions and deletions are compensated by introducing alignment gaps (-). Numbers of unmatched sites $(n)$ and sequence similarity percentages (\%) compared with Uronema nigricans MF072399 and Lembadion lucens MF072398 are also supplied. The two sequences with question marks (?) are possibly misidentified. ID, identical; $n$, numbers of unmatched sites; \%, sequence similarity percentages.

similarity of $99.0 \%$ (Fig. 6). When compared with Uronemita sinensis JN885083 separately, Uronema nigricans MF072399 differs in 40 nucleotides with a sequence similarity of $97.6 \%$ (not shown in the figures or tables). Lembadion lucens MF072398 differs from Lembadion bullinum AF255358 and Lembadion sp. KM222113 in eight and seven nucleotides, respectively (see Fig. 6).

\section{DISCUSSION}

Consideration on three "Uronema nigricans" populations collected from brackish water: Uronema nigricans was first described by Müller (1786) under the name of Cyclidium nigricans and Florentin (1901) transferred it into the genus Uronema. Many populations under the name "Uronema nigricans" were redescribed thereafter (Thompson and Evans 1968, Foissner 1971, Agamaliev 1978, Wilbert and Kahan 1981, Dragesco and Dragesco-Kernéis 1986, Song 1991, Foissner et al. 1994, Yang et al. 2012). Among the descriptions, three populations were collected from brackish water (Thompson and Evans 1968, Agamaliev 1978, Wilbert and Kahan 1981). Since the species in Uronema are usually very small and share many characteristics, misidentification may occur due to the contemporary techniques used and researchers. Consequently, we reinvestigate those three populations.

Thompson and Evans (1968) identified four populations of Uronema nigricans and provided the ciliature information for the species. One of the populations was collected from the mouth of the Pullamadam River in South India. In their opinion, "the river drains into Palk Bay across a wide sand flat by means of several drainage streams and there seemed to be little mixing of the fresh water of the river with the marine water of Palk Bay" (Page 372 in Thompson and Evans, 1968). However, there was no data or evidence to show the salinity of the samples. Consequently, it is possible that no marine water was mixed in the samples and the four populations were all collected from fresh water.

The population described by Agamaliev (1978) was collected from the Caspian Sea (brackish water). Based on the information obtained, we cannot separate the population from Uronema marinum since there are overlaps in many of the characteristics of $U$. marinum and $U$. nigricans, and there was no description of the living observation of this population, which is an important basis for differentiating between these two species (see "Morphological comparison of Uronema nigricans with its congeners" section in the "Discussion" and Table 2). 
We believe that the Red Sea population described by Wilbert and Kahan (1981) was misidentified based on the following: 1) the cell size was relatively smaller than that of other Uronema nigricans populations $(20 \mu \mathrm{m} \times 12 \mu \mathrm{m}$ vs. $20-50 \mu \mathrm{m} \times 10-25 \mu \mathrm{m}) ; 2)$ it possessed a four-rowed M2, diagonally arranged (vs. twoor three-rowed in longitudinal direction); 3) the M3 was almost as large as the M2 (vs. M3 being much shorter than the M2 in other populations); and 4) a unique structure of PM (anterior part in one row and posterior part in a zigzag pattern vs. PM arranged in a zigzag pattern throughout). Therefore, in our opinion the Red Sea population did not represent Uronema nigricans.

Based on the information above, it seems that we could potentially remove "brackish water habitat" from the species diagnosis. However, for the first two populations described, we cannot prove that the brackish water morphotypes are not Uronema nigricans. Consequently, it is better not to remove the "brackish water habitat" from the diagnosis.

Consideration on the "Uronema nigricans" population collected from guppies (Poecilia reticulate): Recently, Yang et al. (2012) identified a scuticociliate from guppies (Poecilia reticulate) as "Uronema nigricans". According to their description, this species had a facultative parasitic life cycle. The body size in vivo was slightly smaller than that of the Shenzhen population $(25-30 \mu \mathrm{m} \times 10-15 \mu \mathrm{m}$ vs. $30-40 \mu \mathrm{m} \times 12-20 \mu \mathrm{m}$ in the Shenzhen population, cell size data are from living cells). In addition, the numbers of SKs differed slightly (13-14 vs. $13-15$ in the Shenzhen population).

However, when we reinvestigated the photomicrographs, we found that the species described by Yang et $a l$. had some features which were quite different from those of the Shenzhen population of Uronema nigricans: 1 ) the posterior end of the buccal field was apparently subequatorially positioned (vs. pre-equatorially positioned in the latter); 2) the posterior end of SK1 extended to over four fifths of the cell (vs. to about three fourths of the cell in the latter); 3) the M1 composed of three to five basal bodies (vs. five or six basal bodies in the latter); 4) the M3 was larger in proportion, almost equals M2 in length (vs. M3 was much shorter than M2 in the latter). Since there were limited photomicrographs to reveal the ciliature, more comparisons cannot be made between them (Yang et al. 2012).

Based on the information above, we believe that the population of "Uronema nigricans" described by Yang et al. (2012) was possibly misidentified, that is, the population may represent another independent species.
Comparison of the Shenzhen population of Uronema nigricans with other populations: The species has been redescribed many times with different populations, and here we make comparisons between the Shenzhen population and others (Thompson and Evans 1968, Foissner 1971, Agamaliev 1978, Dragesco and DragescoKernéis 1986, Song 1991, Foissner et al. 1994).

The Shenzhen population resembles the original description with regard to cell size and shape. However, information on many diagnostic characteristics is lacking in the original description and further comparisons cannot be made (Müller 1786). In terms of body size, shape, buccal apparatus and somatic ciliature, the current population corresponds well with the following populations whose ciliature data are available, thereby suggesting their conspecificity.

Thompson and Evans (1968) described four populations of Uronema nigricans by providing detailed information. In comparison to the four populations, the Shenzhen population has a relatively larger body size (21-29 $\mu \mathrm{m} \times 10-14 \mu \mathrm{m}$ vs. $25-35 \mu \mathrm{m} \times 12-18 \mu \mathrm{m}$ in the Shenzhen population; please note that all data are from impregnated individuals), and more SKs (11-13 vs. 13-15).

Uronema parduczi was described by Foissner (1971) as a new species but was treated as a junior synonym of U. nigricans (Foissner et al. 1994). The form is similar to the Shenzhen population in cell size, but has slightly fewer SKs (11-13 vs. 13-15). The SK1 is longer than that of the Shenzhen population (depicted from the photomicrographs in Foissner 1971).

When compared with the Caspian Sea population (Agamaliev 1978), the Shenzhen population possesses a smaller body size $(30-40 \times 20 \mu \mathrm{m}$ vs. $25-35 \mu \mathrm{m}$ $\times 12-18 \mu \mathrm{m}$ in the Shenzhen population, data are from impregnated individuals) and fewer somatic kineties (13 vs. 13-15, usually 14 in the Shenzhen population).

The population described by Dragesco and Dragesco-Kernéis (1986) has a smaller body size (20-30 $\times 11-14 \mu \mathrm{m}$ vs. $30-40 \mu \mathrm{m} \times 12-20 \mu \mathrm{m}$ in the Shenzhen population, data are from living cells) and fewer somatic kineties (11-13 vs. 13-15) when contrasted with the Shenzhen population.

The Shenzhen population resembles the German population most (Song 1991). A minor difference lies in the number of somatic kineties: 13-15 (usually 14) in the former vs. 13-14 (usually 13) in the latter.

The population described by Foissner et al. (1994) also had fewer somatic kineties when compared to the Shenzhen population (11-13 vs. 13-15). 
It is noticeable that among all the populations mentioned above, only the descriptions by Agamaliev (1978) and Song (1991) provided the number of kinety rows in M2. The number in the former was two; while the number in the latter population was three (vs. two or three rows in the M2 of the Shenzhen population).

Morphological comparison of Uronema nigricans with its congeners (Table 2): In general, species in the genus Uronema share a similar cell size and almost identical body shape. Consequently, it is difficult to distinguish them through live observation alone. However, since $U$. parduczi became a synonym of $U$. nigricans (Foissner et al. 1994), the species seems to be the only nominal species that can live in freshwater habitats so far.

In spite of its habitat, the characteristics of Uronema nigricans resemble those of other Uronema species; therefore, a comparison of these characteristics is necessary. In terms of the number of somatic kineties, $U$. nigricans should be compared with three species: U. marinum Dujardin, 1841; U. gallicum Pérez-Uz and Song, 1995; and U. heteromarinum Pan et al., 2010 (Thompson and Evans 1968, Song 1991, Foissner et al. 1994, Pérez-Uz and Song 1995, Song et al. 2009, Pan H. et al. 2010). For the comparisons of $U$. elegans and $U$. orientalis with $U$. nigricans, see Table 2.

Uronema nigricans differs from $U$. marinum by having different body features: the pellicle is inconspicuously notched with ridges located longitudinally along ciliary rows in the former, and the pellicle is smooth without ridges in the latter. Additionally, the M1 in U. nigricans is clearly separated from other membranelles, while the gap between M1 and M2 in $U$. marinum is relatively small (Thompson and Evans 1968, Song 1991, Foissner et al. 1994, Song et al. 2009, Pan H. et al. 2010).

Uronema nigricans can be distinguished from $U$. gallicum mainly by the structure of its buccal apparatus. In $U$. gallicum, the buccal area is large and occupies about two-thirds of the cell length. By contrast, it occupies approximately $40 \%$ of the cell length in $U$. $n i$ gricans. The M1 in U. gallicum is composed of six or seven widely spaced kinetosomes in a row that sometimes seems to break in the middle. In $U$. nigricans, the kinetosomes are not widely arranged, and no breaks are observed in the middle of M1 (Thompson and Evans 1968, Song 1991, Foissner et al. 1994, Pérez-Uz and Song 1995).

Uronema heteromarinum can be distinguished from $U$. nigricans by its notched pellicle with conspicuous reticulate ridges (in contrast to the inconspicuously notched pellicle without reticulate ridges in U. nigricans) and the number of SKs (15 or 16 vs. $10-15$ in U. nigricans) (Thompson and Evans 1968, Song 1991, Foissner et al. 1994, Pan H. et al. 2010).

As mentioned in the "SSU rDNA sequence and phylogenetic analyses" section under the "Results", the SSU rDNA sequence of Uronema nigricans is placed in a clade with Uronemita sinensis. Here, we also provide a comparison of the two species.

Uronema nigricans and Uronemita sinensis possess similar body size and shape. The latter can be differentiated from $U$. nigricans by its bodily features (the surface of the cell is smooth, without ridges; extrusomes are rod-shaped, about $2 \mu \mathrm{m}$ long vs. pellicle thin and inconspicuously notched, with ridges located longitudinally along ciliary rows; no extrusomes are detected in vivo in $U$. nigricans), a unique M1 structure (consisting of two or three basal bodies in a short row vs. a single-rowed M1 with about five to seven basal bodies in U. nigricans), the relatively longer somatic cilia (about $10 \mu \mathrm{m}$ long vs. 5-7 $\mu \mathrm{m}$ ), fewer somatic kineties (nine to 10 vs. 10 15), a larger macronucleus $(10-18 \mu \mathrm{m}$ in diameter vs. $8-11 \mu \mathrm{m})$, and the marine habitat in which it lives (vs. fresh and brackish water) (Pan X. et al. 2013).

Besides, Uronema nigricans usually has a shorter SK1, with the posterior end extends at about three fourths to four fifths of the body, which separated U. nigricans from its congeners (Thompson and Evans 1968, Song 1991, Foissner et al. 1994, Pan H. et al. 2010).

Comparison of the Zhanjiang population of Lembadion lucens with other populations (Table 3): Lembadion lucens has been described several times since it was originally reported (Maskell 1887, Kahl 1931, Dragesco and Dragesco-Kernéis 1986, Guinea et al. 1990, Foissner et al. 1994, Asadullayeva and Alekperov 2007). The population in the current study corresponds well with the original description (Maskell 1887) in terms of the body shape, size of the buccal field, shape of the macronucleus, and the manner of locomotion. The body size of the population described by Maskell was slightly larger than that of the Zhanjiang population $(62.5 \mu \mathrm{m} \times 43.7 \mu \mathrm{m}$ vs. $53 \mu \mathrm{m} \times 40 \mu \mathrm{m}$ on average). Our population is also smaller than the population depicted by Kahl (the size in vivo of our population is $45-70 \mu \mathrm{m}$ in length vs. $80-100 \mu \mathrm{m}$ ).

In comparison to our population, the population observed by Dragesco and Dragesco-Kernéis (1986) was similar in its number of SKs (25-30). However, the latter had a more rounded body shape (vs. an elliptical 


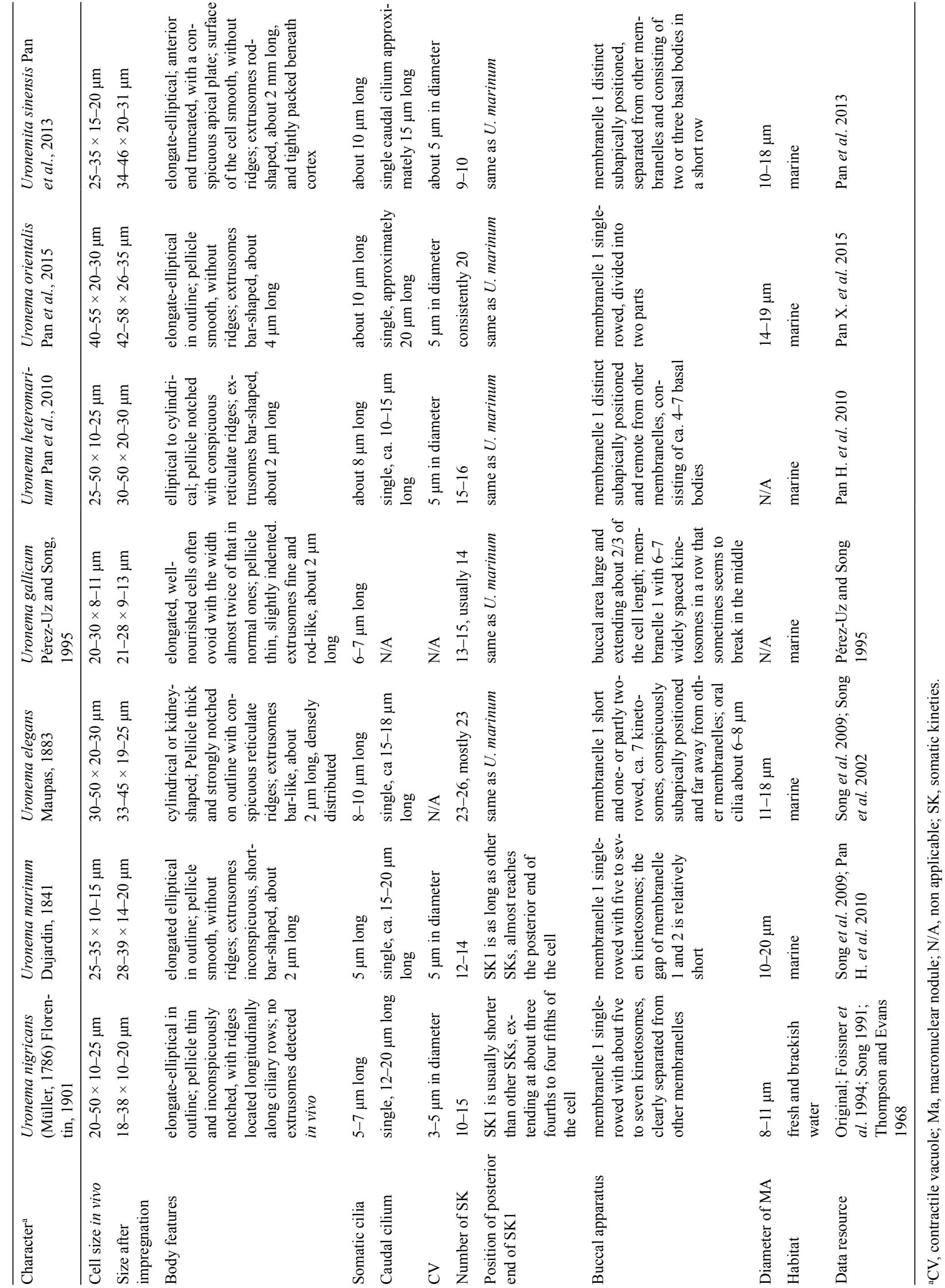




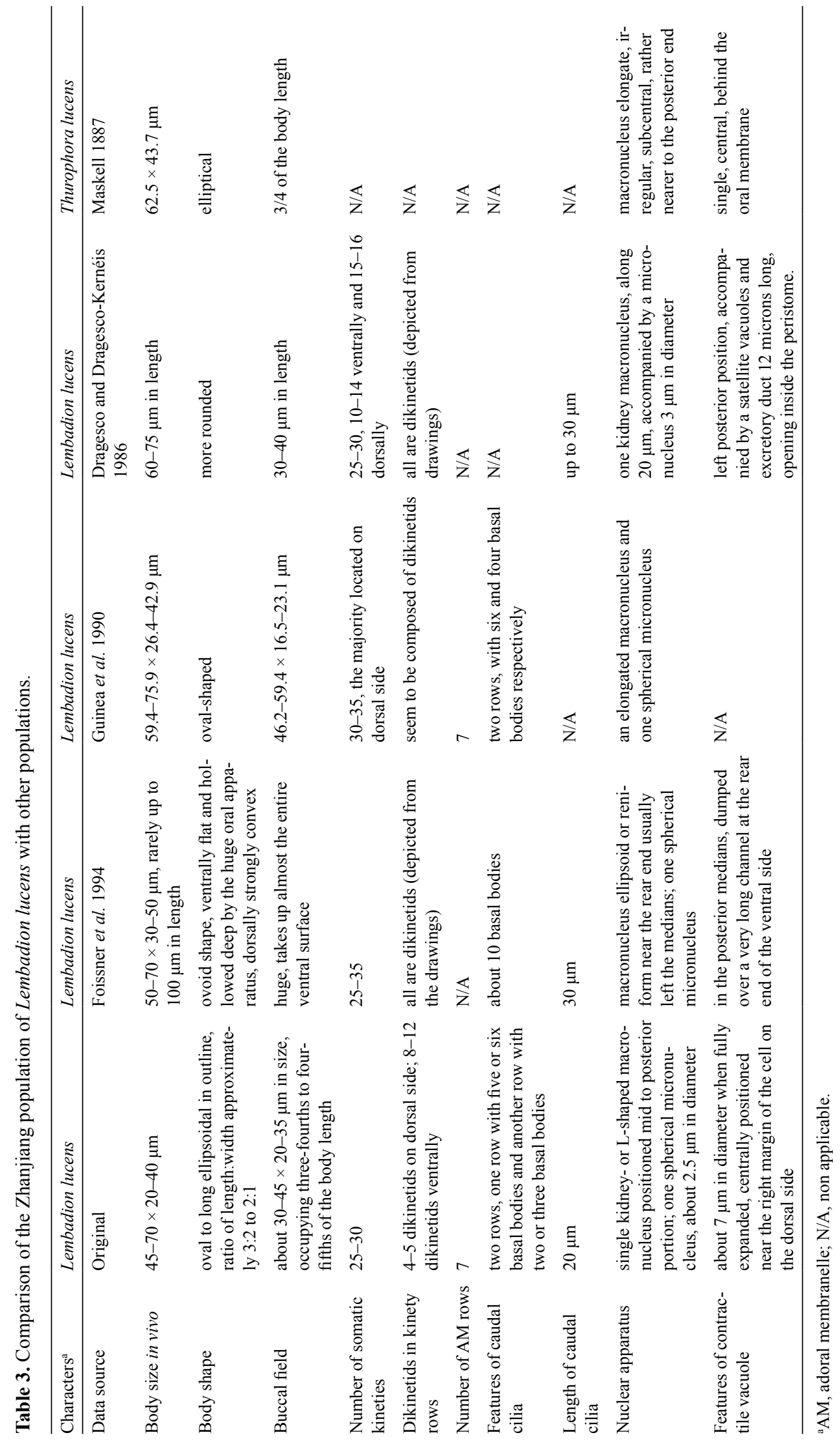




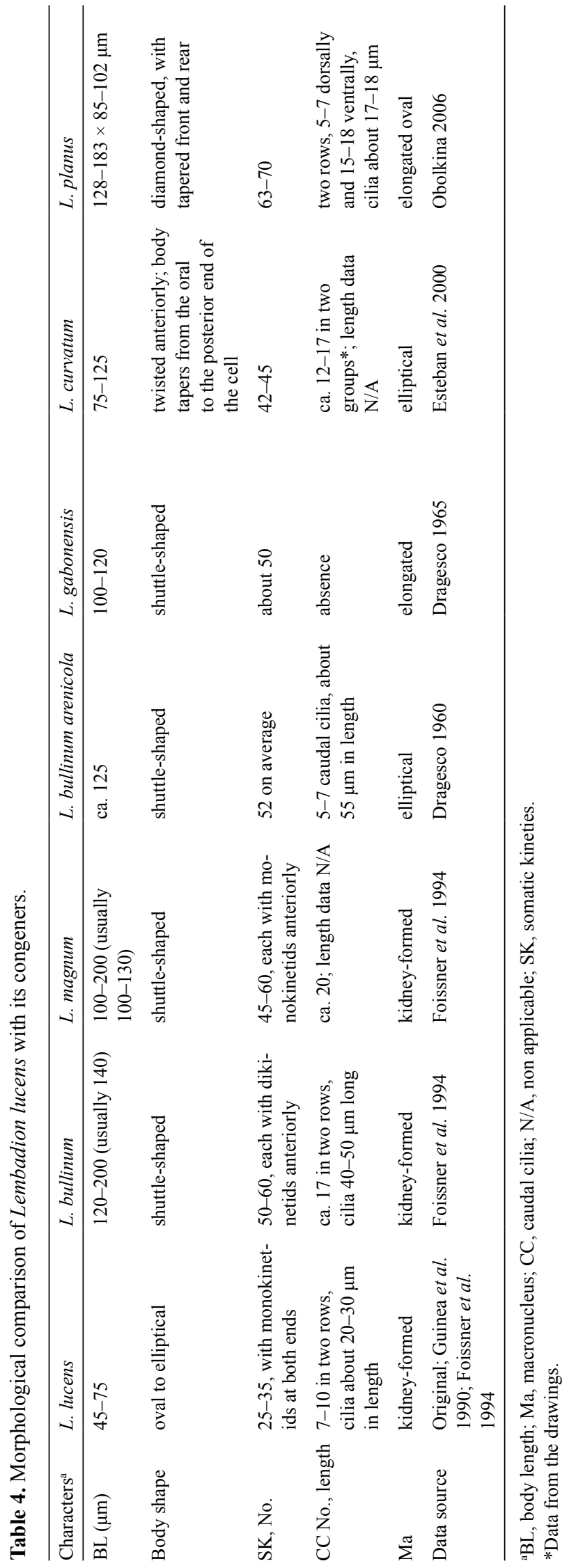

shape in our population), longer caudal cilia (up to 30 $\mu \mathrm{m}$ vs. $20 \mu \mathrm{m})$, and a smaller macronucleus $(20 \mu \mathrm{m}$ in length vs. $15-30 \mu \mathrm{m}$, with an average length of $25 \mu \mathrm{m}$ in our population) (Dragesco and Dragesco-Kernéis 1986).

The population described by Guinea et al. (1990) had similar cell size, cell shape, and buccal field size as the Zhanjiang population. Minor differences were found in the number of SKs (30-35 vs. 25-30 in the Zhanjiang population), the number of basal bodies in the caudal cilia (10, arranged into two rows vs. seven or eight in two rows in the Zhanjiang population), and the number of dikinetids in SKs (which seemed to be composed of dikinetids in each SK vs. four or five dikinetids in the dorsal SKs and eight to 12 dikinetids in the ventral SKs in the Zhanjiang population). However, these dissimilarities are believed to be population dependent.

The population that Foissner et al. (1994) described had a slightly larger cell size than ours $(50-70 \mu \mathrm{m} \times 30$ $50 \mu \mathrm{m}$, rarely up to $100 \mu \mathrm{m}$ in length, vs. $45-70 \mu \mathrm{m}$ $\times 20-40 \mu \mathrm{m}$ ) and more caudal cilia (about 10 vs. seven or eight), as well as more SKs (25-35 vs. 25-30 in the Zhanjiang population). In our opinion, these dissimilarities are also believed to be population dependent.

In Asadullayeva and Alekperov's (2007) description, the Iranian population had slightly fewer basal bodies of caudal cilia (seven in the Iranian population vs. seven or eight, arranged into two rows in the Zhanjiang population) and fewer SKs (19-23 vs. 25-30 in the Zhanjiang population), which seemed to be composed of dikinetids (vs. four or five dikinetids in the dorsal SKs and eight to 12 dikinetids in the ventral SKs in the Zhanjiang population).

Comparison of Lembadion lucens with its congeners (Table 4): At present, the genus Lembadion is comprised of seven species, six of which can be compared to Lembadion lucens.

Lembadion bullinum (Müller, 1786) Perty, 1849 is much larger than L. lucens (about 120-200 $\mu \mathrm{m} \times 70$ $120 \mu \mathrm{m}$ and usually $140 \mu \mathrm{m}$ in length in vivo vs. $45-75$ $\mu \mathrm{m} \times 20-50 \mu \mathrm{m}$ ) and has an elongated body shape (vs. oval to elliptical). Additionally, L. bullinum possesses much more somatic kineties with dikinetids in the posterior part (50-60 longitudinal SKs vs. 25-35 SKs in L. lucens, with the anterior and posterior ends consisting of monokinetids and mid-portion dikinetids). Lembadion bullinum also has more and longer caudal cilia than L. lucens (about 17 kinetids of caudal cilia arranged into two rows with cilia that are 40-50 $\mu \mathrm{m}$ long 
vs. seven to 10 kinetids in two rows, and cilia about 20-30 $\mu \mathrm{m}$ in length) (Maskell 1887, Dragesco and Dragesco-Kernéis 1986, Guinea et al. 1990, Foissner et al. 1994).

Lembadion magnum (Stokes, 1887) Kahl, 1931 has a larger cell size and a shuttle-shaped outline (100-200 $\mu \mathrm{m} \times 50-100 \mu \mathrm{m}$, usually $100-130 \mu \mathrm{m}$ long) compared to $L$. lucens, which has a smaller cell size $(45-75 \mu \mathrm{m}$ $\times 20-50 \mu \mathrm{m})$ and an oval to elliptical body shape. In addition, L. magnum has more somatic kineties, consisting of monokinetids at the anterior end (45-60 SKs in L. magnum vs. 25-35 SKs in L. lucens, with monokinetids at both termini of the SKs). Lembadion magnum also has more caudal cilia than L. lucens (approximately 20 in number vs. seven to 10 kinetids in two rows) (Maskell 1887, Dragesco and Dragesco-Kernéis 1986, Guinea et al. 1990, Foissner et al. 1994).

According to Dragesco (1960), Lembadion bullinum arenicola can be distinguished from $L$. lucens with its larger body size (125 $\mu \mathrm{m}$ average length vs. $45-75 \mu \mathrm{m}$ $\times 20-50 \mu \mathrm{m}$ in L. lucens), greater number of SKs (52 on average vs. 25-35 in L. lucens), and an oval macronucleus with slightly pointed ends (vs. a kidney-shaped macronucleus in L. lucens). Lembadion bullinum arenicola also possesses more caudal cilia than L. lucens (five to seven, about $55 \mu \mathrm{m}$ in length vs. seven to 10 , 20-30 $\mu \mathrm{m}$ long) (Maskell 1887, Dragesco 1960, Dragesco and Dragesco-Kernéis 1986, Guinea et al. 1990, Foissner et al. 1994).

Lembadion gabonensis Dragesco, 1965 differs from L. lucens mainly in the absence of caudal cilia (vs. seven to 10 kinetids in two rows in L. lucens). In addition, L. gabonensis is larger (with a body length of about $100-120 \mu \mathrm{m}$ vs. $45-75 \mu \mathrm{m}$ in L. lucens) and possesses more SKs (about 50 vs. 25-35 in L. lucens) (Maskell 1887, Dragesco 1965, Dragesco and Dragesco-Kernéis 1986, Guinea et al. 1990, Foissner et al. 1994).

Lembadion curvatum Esteban et al., 2000 is easily distinguished from $L$. lucens based on its body size (75-125 $\mu \mathrm{m} \times 45-65 \mu \mathrm{m}$ vs. $45-75 \mu \mathrm{m} \times 20-50 \mu \mathrm{m}$ in L. lucens) and shape (widened and twisted anteriorly, slender behind the oral region, and tapered towards the posterior end of the cell, forming a sinusoidal shape in outline vs. oval to elliptical in L. lucens). In addition, the former has more SKs (42-45 vs. $25-35$ in $L$. lucens) and more caudal cilia (about $12-17$ basal bodies arranged into two groups vs. seven to 10 kinetids in two rows in L. lucens) (Maskell 1887, Dragesco and Dragesco-Kernéis 1986, Guinea et al. 1990, Foissner et al. 1994, Esteban et al. 2000).
Lembadion planus Obolkina, 2006 has a larger cell size $(128-183 \times 85-102 \mu \mathrm{m}$ vs. $45-75 \mu \mathrm{m} \times 20-50 \mu \mathrm{m}$ in L. lucens), a different body shape (diamond shaped, with tapered front and rear vs. oval to elliptical in L. lucens) and an oval macronucleus (vs. a kidney-shaped macronucleus in L. lucens). The species also has much more SKs (63-70 vs. $25-35)$ and more caudal cilia with a short length (five to seven dikinetids on the dorsal side and $15-18$ on the ventral side, caudal cilia $17-18 \mu \mathrm{m}$ vs. five or six kinetids on the dorsal side and two to four on the ventral side, caudal cilia 20-30 $\mu \mathrm{m}$ long in L. lucens) (Maskell 1887, Dragesco and DragescoKernéis 1986, Guinea et al. 1990, Foissner et al. 1994, Obolkina 2006). Consequently, these two species will not be confused.

Phylogenetic analyses of the Shenzhen population of Uronema nigricans (Figs 5 and 6): As mentioned above, the SSU rDNA sequence of the Shenzhen population of Uronema nigricans and two other sequences under the name of "U. nigricans" were deposited in the Uronemita clade and clustered with Uronemita sinensis with full support.

The sequence of the Shenzhen population of Uronema nigricans (MF072399) differs from the other two sequences (JF973324, JN638884, both from Yang et al. 2012) in 10 nucleotides, respectively, and the sequence similarity between them are $99.0 \%$. In our opinion, such a difference in SSU rDNA (of which the sequence is extremely conservative) may propose separated species. As mentioned in "Consideration on the 'Uronema nigricans' population collected from guppies (Poecilia reticulate)" in "Discussion", we find several features that differs between the species described by Yang et al. and the Shenzhen population of U. nigricans, indicating that they represent separated species. Both morphological and molecular information show that the species in Yang et al. (2012) is possibly misidentified. We have marked the two sequences extracted from this species (JF973324, JN638884) with question marks in Figs 5 and 6.

Discussion on the taxonomic status of Uronemita sinensis (Figs 5 and 6, Table 2): Based on the phylogeny results (the sequence of Uronema nigricans was deposited in the Uronemita clade and clustered with Uronemita sinensis with full support, see Fig. 5), we may pose the following questions: Should Uronema nigricans be transferred into the genus Uronemita? Does Uronemita sinensis resemble Uronema nigricans more than other Uronemita species on both morphological and molecular levels? 
Uronema nigricans has many aspects that not conform to the improved diagnosis of the genus Uronemita: 1) the cytostome of Uronema nigricans is not subequatorially positioned; 2) the locomotion of Uronema nigricans is not the typical "rotation movement" of Uronemita; and 3) Uronema nigricans is a freshwater species (Liu et al. 2016). In conclusion, Uronema nigricans should not be transferred into the genus Uronemita.

Uronemita sinensis was reported by Pan X. et al. (2013) as a new species. The species matches the genus diagnosis (improved by Pan X. et al. 2013) in having an elongate-elliptical outline with a truncated apical frontal plate, subequatorially positioned cytostome, and a marine habitat. However, in the description of Uronemita sinensis, its locomotion was described as "swimming moderately fast while rotating about the main body axis, sometimes quiet on the bottom" (Pan X. et al. 2013). It did not mention whether the species had a "rotation movement", which, in our opinion, is a very important feature in species identification (Liu et al. 2016). Additionally, the widest part of the cell in Uronemita sinensis is at the mid portion with a small apical plate at the front end, which resembles Uronema marinum, the type of the genus Uronema (Song et al. 2009, Pan H. et al. 2010, Pan X. et al. 2013). Furthermore, Uronemita sinensis resembles the Uronema species (U. marinum, $U$. nigricans, and $U$. gallicum) in some body features (e.g., cell outline, position of the widest part of the body, and the relative size of the apical plate) and locomotion (e.g., swimming while rotating, crawling on substrates, or resting on the bottom) (Pérez-Uz and Song 1995, Song et al. 2009, Pan H. et al. 2010).

Uronemita sinensis differs from species of Uronema and Uronemita in having fewer basal bodies in M1: the former has a single-row M1 with two or three basal bodies (vs. four to seven basal bodies in the Uronema and Uronemita species) (Pan X. et al. 2013). For the Uronema species, see Table 2; for other Uronemita species, refer to the 'Data resource' of Table 3 in Liu et al. 2016.

In addition to the morphological differences, the SSU rDNA sequence of Uronemita sinensis differs from those of other Uronemita species in 76-82 nucleotides and having a sequence similarity from $95.0 \%$ to $95.3 \%$ (not shown in this work). By contrast, Uronemita sinensis JN885083 has relatively fewer differences when compared separately to Uronema nigricans MF072399 (with 40 different sites and 97.6\% sequence similarity, but not shown in this work as mentioned in the "Results").
In conclusion, Uronemita sinensis is closer to the Uronema species than it is to the Uronemita species based on both morphological and molecular data. In our opinion, it is better to transfer this species out of Uronemita. However, because of the following, more investigations should be conducted to determine the taxonomic status of Uronemita sinensis: 1) Uronemita sinensis has a combination of characteristics from both Uronemita and Uronema; 2) the SSU rDNA sequence of Uronemita sinensis differs from those of other Uronemita or Uronema species by over 38 nucleotides; and 3) the structure of M1 in Uronemita sinensis is very unique. Therefore, the current Uronemita sinensis may actually represent a distinct genus. If so, the genus Uronemita would remain monophyletic.

Phylogenetic analyses of the Zhanjiang population of Lembadion lucens (Figs 5 and 6): The SSU rDNA sequence of the Zhanjiang population of Lembadion lucens (MF072398) is placed with those of L. bullinum AF255358 and Lembadion sp. KM222113, forming a monophylum with maximum support (100\% ML, 1.00 BI). Phylogenetically, Lembadion lucens MF072398 is most closely related to Lembadion sp. KM222113 (with seven different nucleotides, see Fig. 6). However, since the morphological information on Lembadion $\mathrm{sp}$. KM222113 is lacking, a comparison of the two species cannot be completed. The SSU rDNA sequence of Lembadion lucens differs from L. bullinum AF255358 in eight sites (Fig. 6). For L. bullinum AF255358, since the morphological information is not available, we are not sure of the correctness of the identification of this sequence. For L. lucens MF072398, which we submitted, the Zhanjiang population of $L$. lucens corresponds well with the original and previous descriptions, and it can be separated from L. bullinum clearly (see "Discussion"); therefore, the identification is correct. To summarize, L. lucens MF072398 combines morphological information and this sequence represents the species Lembadion lucens; since there is no morphological data on the sequence L. bullinum AF255358, the possibility of misidentification cannot be excluded.

Acknowledgments. We are grateful to the anonymous reviewers who read an earlier version of this paper for their thoughtful comments that led to improvements in the manuscript. This work was supported by the Natural Science Foundation of China (project numbers: 41576134 and 31470064) and the Deanship of Scientific Research at King Saud University (PRG-1436-24). We would also like to thank Professor Weibo Song (OUC) for his critical help in the drafting of this manuscript. 


\section{REFERENCES}

Agamaliev F. G. (1978) Morphology of some free-living ciliates of the Caspian Sea. Acta Protozool. 17: 419-444

Asadullayeva E., Alekperov I. (2007) Free-living ciliates of the Anzali Wetland of the Caspian Sea. Turk. J. Zool. 31: 143-149

Chantangsi C., Lynn D. H., Rueckert S., Prokopowicz A. J., Panha S., Leander B. S. (2013) Fusiforma themisticola n. gen., n. sp., a new genus and species of apostome ciliate infecting the hyperiid amphipod Themisto libellula in the Canadian Beaufort Sea (Arctic Ocean), and establishment of the Pseudocolliniidae (Ciliophora, Apostomatia). Protist 164: 793-810

de Castro L. A. M., Kuppers G. C., Schweikert M., Harada M. L., Paiva T. D. (2014) Ciliates from eutrophized water in the northern Brazil and morphology of Cristigera hammeri Wilbert, 1986 (Ciliophora, Scuticociliatia). Eur. J. Protistol. 50: 122-133

de Puytorac P., Grolière C., Roque M., Detcheva R. (1974) A propos d'un cilié Philasterina trouvé dans la cavité générale du polychète Nereis diversicolor O. F. Muller. Protistologica (Paris) 10: 101-111 (in French)

Dragesco J. (1960) Ciliés mésopsammiques littoraux, systématique, morphologie, écologie. Trav. Stat. Biol. Roscoff (N. S.) 12: $1-356$

Dragesco J. (1965) Ciliés mésopsammiques dAfrique Noire. Cah. Biol. Mar. 6: 357-399

Dragesco J., Dragesco-Kernéis A. (1986) Ciliés libres de l'Afrique intertropicale. Introduction à la connaissance et àl'étude des Ciliés. Faune Tropicale 26: 1-559

Dujardin F. (1841) Histoire Naturelle des Zoophytes. Infusoires, Paris

Esteban G. F., Finlay B. J., Olmo J. L., Tyler P. A. (2000) Ciliated protozoa from a volcanic crater-lake in Victoria, Australia. J. Nat. Hist. 34: 159-189

Fan X., Chen X., Song W., Al-Rasheid K. A. S., Warren A. (2011a) Two novel marine Frontonia species, Frontonia mengi spec. nov. and Frontonia magna spec. nov. (Protozoa; Ciliophora), with notes on their phylogeny based on small-subunit rRNA gene sequence data. Int. J. Syst. Evol. Microbiol. 61: 1476-1486

Fan X., Lin X., Al-Rasheid K. A. S., Warren A., Song W. (2011b) The diversity of scuticociliates (Protozoa, Ciliophora): A report on eight marine forms found in coastal waters of China, with a description of one new species. Acta Protozool. 50: 219-234

Feng J., Jiang C., Warren A., Tian M., Cheng J., Liu G., Xiong J., Miao W. (2015) Phylogenomic analyses reveal subclass Scuticociliatia as the sister group of subclass Hymenostomatia within class Oligohymenophorea. Mol. Phylogenet. Evol. 90: 104-111

Florentin R. (1901) Description de deux infusoires ciliés nouveaux des mares salées de Lorraine suivie de quelques considérations sur la faune des lacs salés. Annls Sci. Nat. (Zool.) 12: 343-363

Foissner W. (1971) Das silberliniensystem von Uronema parduczi sp. n. (Ciliata, Hymenostomatida, Uronematidae). Arch. Protistenkd. 113: 34-50

Foissner W. (1995) Tropical protozoan diversity: 80 ciliate species (Protozoa, Ciliophora) in a soil sample from a tropical dry forest of Costa Rica, with descriptions of four new genera and seven new species. Arch. Protistenkd. 145: 37-79

Foissner W., Berger H., Kohmann F. (1994) Taxonomische und ökologische Revision der Ciliaten des Saprobiensystems Band III: Hymenostomata, Prostomatida, Nassulida. Informationsber. Bayer. Landesamtes Wasserwirtsch 1/94: 1-548

Gao F., Katz L. A. (2014) Phylogenomic analyses support the bifurcation of ciliates into two major clades that differ in properties of nuclear division. Mol. Phylogenet. Evol. 70: 240-243
Gao F., Fan X., Yi Z., Strüder-Kypke M., Song W. (2010) Phylogenetic consideration of two scuticociliate genera, Philasterides and Boveria (Protozoa, Ciliophora) based on 18S rRNA gene sequences. Parasitol. Int. 59: 549-555

Gao F., Katz L. A., Song W. (2012) Insights into the phylogenetic and taxonomy of philasterid ciliates (Protozoa, Ciliophora, Scuticociliatia) based on analyses of multiple molecular markers. Mol. Phylogenet. Evol. 64: 308-317

Gao F., Katz L. A., Song W. (2013) Multigene-based analyses on evolutionary phylogeny of two controversial ciliate orders: Pleuronematida and Loxocephalida (Protista, Ciliophora, Oligohymenophorea). Mol. Phylogenet. Evol. 68: 55-63

Gao F., Gao S., Wang P., Katz L. A., Song W. (2014) Phylogenetic analyses of cyclidiids (Protista, Ciliophora, Scuticociliatia) based on multiple genes suggest their close relationship with thigmotrichids. Mol. Phylogenet. Evol. 75: 219-226

Gao F., Warren A., Zhang Q., Gong J., Miao M., Sun P., Xu D., Huang J., Song W. (2016) The all-data-based evolutionary hypothesis of ciliated protists with a revised classification of the phylum Ciliophora (Eukaryota, Alveolata). Sci. Rep. 6: 24874

Guinea A., Sola A., Longas J., Fernandez-Galiano D. (1990) Morphology and morphogenesis of two species of the genus Lembadion (Ciliophora, Oligohymenophora): Lembadion lucens and Lembadion bullinum. J. Protozool. 37: 553-561

Hall T. A. (1999) BioEdit: a user-friendly biological sequence alignment editor and analysis program for Windows 95/98/NT. Nucleic Acids Symp. Ser. 41: 95-98

Huang J., Chen Z., Song W., Berger H. (2014) Three-gene based phylogeny of the Urostyloidea (Protista, Ciliophora, Hypotricha), with notes on classification of some core taxa. Mol. Phylogenet. Evol. 70: 337-347

Jankowski A. W. (2007) Phylum Ciliophora Doflein, 1901. In: Protisca. Part 2. Handbook on Zoology, (Ed. A. F. Alimov). Russian Academy of Sciences, Zoological Institute, St. Petersburg, 415-993 (in Russian with English summary)

Kahl A. (1931) Urtiere oder Protozoa I: Wimpertiere oder Ciliata (Infusoria). 2. Holotricha. Tierwelt. Dtl. 21: 181-398

Kaneshiro E. S., Holz G. G. (1976) Observations on the ultrastructure of Uronema spp., marine scuticociliates. J. Protozool. 23: 503-517

Liu M., Gao F., Al-Farraj S. A., Hu X. (2016) Morphology and small subunit rRNA gene sequence of Uronemita parabinucleata n. sp. (Ciliophora, Uronematidae), with an improved generic diagnosis. Eur. J. Protistol. 54: 1-10

Lynn D. H. (2008) The ciliated protozoa: characterization, classification, and guide to the literature, third ed. Springer, Dordrecht

Lynn D. H., Small E. B. (2002) An illustrated guide to the protozoa. Phylum Ciliophora. Society of Protozoologists, Lawrence, Kansas

Lynn D. H., Strüder-Kypke M. (2005) Scuticociliate endosymbionts of echinoids (phylum Echinodermata): phylogenetic relationships among species in the genera Entodiscus, Plagiopyliella, Thyrophylax, and Entorhipidium (phylum Ciliophora). J. Parasitol. 91: 1190-1199

Ma H., Song W. (2003) Stomatogenesis of the marine ciliate Metanophrys sinensis (Protozoa: Ciliophora: Scuticociliatida). J. Mar. Biol. Ass. U. K. 83: 407-410

Ma H., Gong J., Song W. (2003) Stomatogenesis of the marine ciliate Pleuronema coronatum Kent, 1881 (Ciliophora, Scuticociliatida). Acta Zool. Sin. 49: 829-834

Ma H., Song W., Gong J., Warren A. (2004) Reconsideration of stomatogenesis in Uronema marinum Dujardin, 1841 during 
asexual division (Protozoa: Ciliophora: Scuticociliatida). Acta Zool. Sin. 50: $823-827$

Ma H., Song W., Warren A., Roberts D., Gong J., Al-Rasheid K. A. S. (2006) Redescription of the marine scuticociliate Glauconema trihymene Thompson, 1966 (Protozoa; Ciliophora): life cycle and stomatogenesis. Zootaxa 1296: 1-17

Maskell W. (1887) On the freshwater Infusoria of Wellington district. Trans. NZ Inst. 20: 1-19

Miao M., Warren A., Song W., Wang S., Shang H., Chen Z. (2008) Analysis of the internal transcribed spacer 2 (ITS2) region of scuticociliates and related taxa (Ciliophora, Oligohymenophorea) to infer their evolution and phylogeny. Protist 159: 519-533

Miao M., Wang Y., Li L., Al-Rasheid K. A. S., Song W. (2009) Molecular phylogeny of the scuticociliate Philaster (Protozoa, Ciliophora) based on SSU rRNA gene sequences information, with description of a new species $P$. apodigitiformis sp. n. Syst. Biodivers. 7: 381-388

Miao M., Wang Y., Song W., Clamp J. C., Al-Rasheid K. A. S. (2010) Description of Eurystomatella sinica n. gen., n. sp., with establishment of a new family Eurystomatellidae n. fam. (Protista, Ciliophora, Scuticociliatia) and analyses of its phylogeny inferred from sequences of the small-subunit rRNA gene. Int. J. Syst. Evol. Microbiol. 60: 460-468

Medlin L., Elwood H. J., Stickel S., Sogin M. L. (1988) The characterization of enzymatically amplified eukaryotes 16S-like ribosomal RNA coding regions. Gene 71: 491-500

Miller M. A., Pfeiffer W., Schwartz T. (2010) Creating the CIPRES science gateway for inference of large phylogenetic trees. In: Proceedings of the Gateway Computing Environments Workshop (GCE), New Orleans, LA

Nylander J. A. A. (2004) MrModeltest version 2. Evolutionary Biology Centre, Uppsala University, Uppsala

Obolkina L. A. (2006) The new species, Lembadion planus (Peniculida, Ciliophora), from Lake Baikal. Zool. Zh. 85: 114-118 (in Russian with English summary)

Pan H., Huang J., Hu X., Fan X., Al-Rasheid K. A. S., Song W. (2010) Morphology and SSU rRNA gene sequences of three marine ciliates from Yellow Sea, China, including one new species, Uronema heteromarinum nov. spec. (Ciliophora, Scuticociliatida). Acta Protozool. 49: 45-59

Pan H., Hu J., Jiang J., Wang L., Hu X. (2016) Morphology and phylogeny of three Pleuronema species (Ciliophora, Scuticociliatia) from Hangzhou Bay, China, with description of two new species, $P$. binucleatum n. sp. and P. parawiackowskii n. sp. J. Eukaryot. Microbiol. 63: 287-298

Pan X., Zhu M., Ma H., Al-Rasheid K. A. S., Hu X. (2013) Morphology and small-subunit rRNA gene sequences of two new marine ciliates, Metanophrys orientalis spec. nov. and Uronemella sinensis spec. nov. (Protista, Ciliophora, Scuticociliatia), with an improved diagnosis of the genus Uronemella. Int. J. Syst. Evol. Microbiol. 63: 3513-3523

Pan X., Huang J., Fan X., Ma H., Al-Rasheid K. A. S., Miao M., Gao F. (2015) Morphology and phylogeny of four marine scuticociliates (Protista, Ciliophora), with descriptions of two new species: Pleuronema elegans spec. nov. and Uronema orientalis spec. nov. Acta Protozool. 54: 31-43

Pan X., Fan X., Al-Farraj S. A., Gao S., Chen Y. (2016) Taxonomy and morphology of four "ophrys-related" scuticociliates (Protista, Ciliophora, Scuticociliata), with the description of a new genus, Paramesanophrys gen. nov. Eur. J. Taxon. 191: 1-18

Pan X., Shi Z., Wang C., Bourland W. A., Chen Y., Song W. (2017) Molecular phylogeny and taxonomy of a new freshwater hy- menostomatid from Northeastern China, with the establishment of a new genus Anteglaucoma gen. n. (Protista, Ciliophora, Oligohymenophorea). J. Eukaryot. Microbiol. 67: 557-564

Pérez-Uz B., Song W. (1995) Uronema gallicum sp. n. (Protozoa: Ciliophora) a new marine scuticociliate from the coastal area of Calais. Acta Protozool. 34: 143-143

Perty M. (1849) Über vertikale Verbreitung mikroskopischer Lebensformen. Naturforschende Gesellschaft in Bern Mittheilungen 1849: 17-45

Petz W., Song W., Wilbert N. (1995) Taxonomy and ecology of the ciliate fauna (Protozoa, Ciliophora) in the endopagial and pelagial of the Weddell Sea, Antarctica. Stapfia 40: 1-223

Ronquist F., Huelsenbeck J. P. (2003) MRBAYES 3: Bayesian phylogenetic inference under mixed models. Bioinformatics 19: $1572-1574$

Schuster L., Bright M. (2016) A novel colonial ciliate Zoothamnium ignavum sp. nov. (Ciliophora, Oligohymenophorea) and its ectosymbiont Candidatus Navis piranensis gen. nov., sp. nov. from shallow-water wood falls. PloS one 11: e0167873. doi: 10.1371/journal.pone.0167873

Shang H., Song W. (2005) Separation and relationship of ten marine scuticociliates (Protozoa, Ciliophora) using RAPD fingerprinting method. Acta Oceanol. Sin. 24: 78-85

Shang H., Song W., Warren A. (2003) Phylogenetic positions of two ciliates, Paranophrys magna and Mesanophrys carcini (Ciliophora: Oligohymenophorea), within the subclass Scuticociliatia inferred from complete small subunit rRNA gene sequences. Acta Protozool. 42: 171-181

Shang H., Song W., Warren A., Li L., Chen Z. (2006) Phylogenetic positions of two marine ciliates, Metanophrys similis and Pseudocohnilembus hargisi (Protozoa, Ciliophora, Scuticociliatia), inferred from complete small subunit rRNA gene sequences. Progr. Nat. Sci. 16: 373-378

Song W. (1991) Morphology and morphogenesis of the fresh-water scuticociliate Uronema nigricans (Müller, 1786). Acta Zool. Sin. 37: 233-243 (in Chinese with English summary)

Song W., Wilbert N. (2000) Ciliates from Antarctic sea ice. Polar Biol. 23: 212-222

Song W., Ma H., Wang M., Zhu M. (2002) Comparative studies on two closely related species Uronemella filificum (Kahl, 1931) and Uronema elegans Maupas, 1883 with redescription of Paranophrys marina Thompson et Berger, 1965 (Ciliophora: Scuticociliatida) from China seas. Acta Protozool. 41: 263-278

Song W., Warren A., Hu X. (2009) Free-living ciliates in the Bohai and Yellow Sea, China, first ed. Science Press, Beijing

Stamatakis A. (2014) RAxML Version 8: A tool for phylogenetic analysis and post-analysis of large phylogenies. Bioinformatics 30: $1312-1313$

Stokes A. C. (1887) Notices of new fresh-water infusoria. Proc. Am. Philos. Soc. 24: 244-255

Strüder-kypke M. C., Wright A. D. G., Fokin S. I., Lynn D. H. (2000) Phylogenetic relationships of the subclass Peniculia (Oligohymenophorea, Ciliophora) inferred from small subunit rRNA gene sequences. J. Eukaryot. Microbiol. 47: 419-429

Tamura K., Dudley J., Nei M., Kumar S. (2007) MEGA 4: molecular evolutionary genetics analysis (MEGA) software Ver. 4.0. Mol. Biol. Evol. 24: 1596-1599

Thompson J. C., Evans F. R. (1968) A redescription of Uronema nigricans. J. Eukaryot. Microbiol. 15: 369-374

Thompson J. C., Kaneshiro E. S. (1968) Redescriptions of Uronema filificum and U. elegans. J. Protozool. 15: 141-144 
Wang Y., Miao M., Zhang Q., Gao S., Song W., Al-Rasheid K. A. S., Warren A., Ma H. (2008) Three marine interstitial scuticociliates, Schizocalyptra similis sp. n., S. sinica sp. n. and Hippocomos salinus Small and Lynn, 1985 (Ciliophora: Scuticociliatida), isolated from Chinese coastal waters. Acta Protozool. 47: $377-387$

Wilbert N. (1975) Eine verbesserte Technik der Protargolimprägnation für Ciliaten. Mikrokosmos 64: 171-179

Wilbert N., Kahan D. (1981) Ciliates of solar lake on the Red Sea shore. Arch. Protistenkd. 124: 70-95

Xiong J., Wang G., Cheng J., Tian M., Pan X., Warren A., Jiang C., Yuan D., Miao W. (2015) Genome of the facultative scuticociliatosis pathogen Pseudocohnilembus persalinus provides insight into its virulence through horizontal gene transfer. Sci. Rep. 5: 15470
Yang L., Pan H., Li H., Li Q., Wu Y. (2012) Confirmation and identification of the pathogen Uronema nigricans in guppy (Poecilia reticulate). Acta Hydrobiol. Sin. 36: 578-582

Zhao Y., Yi Z., Gentekaki E., Zhan A., Al-Farraj S. A., Song W. (2016) Utility of combining morphological characters, nuclear and mitochondrial genes: An attempt to resolve the conflicts of species identification for ciliated protists. Mol. Phylogenet. Evol. 94: 718-729

Received on $11^{\text {th }}$ March, 2017; revised on $5^{\text {th }}$ May, 2017; accepted on $8^{\text {th }}$ June; 2017 